\title{
Learn from Your Elders: Developmental Biology Lessons to Guide Maturation of Stem Cell-Derived Cardiomyocytes
}

\author{
Silvia Marchianò ${ }^{1,2,3} \cdot$ Alessandro Bertero ${ }^{1,2,3} \cdot$ Charles E. Murry ${ }^{1,2,3,4,5}$
}

Received: 4 May 2019 / Accepted: 16 July 2019

○) Springer Science+Business Media, LLC, part of Springer Nature 2019

\begin{abstract}
Human pluripotent stem cells (hPSCs) offer a multifaceted platform to study cardiac developmental biology, understand disease mechanisms, and develop novel therapies. Remarkable progress over the last two decades has led to methods to obtain highly pure hPSC-derived cardiomyocytes (hPSC-CMs) with reasonable ease and scalability. Nevertheless, a major bottleneck for the translational application of hPSC-CMs is their immature phenotype, resembling that of early fetal cardiomyocytes. Overall, bona fide maturation of hPSC-CMs represents one of the most significant goals facing the field today. Developmental biology studies have been pivotal in understanding the mechanisms to differentiate hPSC-CMs. Similarly, evaluation of developmental cues such as electrical and mechanical activities or neurohormonal and metabolic stimulations revealed the importance of these pathways in cardiomyocyte physiological maturation. Those signals cooperate and dictate the size and the performance of the developing heart. Likewise, this orchestra of stimuli is important in promoting hPSC$\mathrm{CM}$ maturation, as demonstrated by current in vitro maturation approaches. Different shades of adult-like phenotype are achieved by prolonging the time in culture, electromechanical stimulation, patterned substrates, microRNA manipulation, neurohormonal or metabolic stimulation, and generation of human-engineered heart tissue (hEHT). However, mirroring this extremely dynamic environment is challenging, and reproducibility and scalability of these approaches represent the major obstacles for an efficient production of mature hPSC-CMs. For this reason, understanding the pattern behind the mechanisms elicited during the late gestational and early postnatal stages not only will provide new insights into postnatal development but also potentially offer new scalable and efficient approaches to mature hPSC-CMs.
\end{abstract}

Keywords Postnatal cardiac development · Human embryonic stem cells · Human induced pluripotent stem cells · Cardiomyocyte maturation

Charles E. Murry

murry@uw.edu

1 Department of Pathology, University of Washington, 1959 NE Pacific Street, Seattle, WA 98195, USA

2 Center for Cardiovascular Biology, University of Washington, 850 Republican Street, Brotman Building, Seattle, WA 98109, USA

3 Institute for Stem Cell and Regenerative Medicine, University of Washington, 850 Republican Street, Seattle, WA 98109, USA

4 Department of Medicine/Cardiology, University of Washington, 1959 NE Pacific Street, Seattle, WA 98195, USA

5 Department of Bioengineering, University of Washington, 3720 15th Ave NE, Seattle, WA 98105, USA

\section{Introduction}

The discovery of human pluripotent stem cells (hPSCs) has revolutionized cardiovascular biology [1-3]. Over the last two decades, methods to differentiate cardiomyocytes from human pluripotent stem cells (hPSCs, either embryonic stem cells-hESCs, or -induced pluripotent stem cells-hiPSCs) have been refined and streamlined [4-7]. State-of-the-art protocols allow the production of highly pure cells with the main features of either working (i.e., ventricular and atrial) or pacemaker myocytes [8-10]. Such bona fide hPSC-derived cardiomyocytes (hPSC-CMs) contract spontaneously and show action potentials and calcium transients similar to their in vivo counterparts. Accordingly, they express the main cardiac ion channels and sarcomeric proteins involved in excitation-contraction coupling. This provides a cost-effective 
and renewable source of cardiomyocytes for a plethora of applications such as developmental biology [11, 12], pharmacology [13, 14], disease modeling [15, 16], and regenerative medicine [17-19]. For instance, hPSC-CMs are becoming a prominent model to evaluate the potential cardiac toxicity of novel drugs, which represents one of the most significant bottlenecks in the drug development pipeline [14, 20, 21]. Moreover, hPSC-CMs are emerging as a promising therapeutic approach for cardiac regeneration [22, 23], as their transplantation into infarcted hearts of nonhuman primates leads to efficient remuscularization and electrical coupling, which can prevent adverse remodeling of the myocardium and restore its mechanical function $[19,22,24]$.

Despite these exciting applications, a major obstacle that prevents harnessing the full potential of hPSC-CMs is represented by their immature phenotype. Among other features, hPSC-CMs are a fraction of the size of adult cells, are much weaker, exhibit persistent automaticity and lack their typical rod-shaped morphology. Moreover, hPSC-CMs are metabolically dependent on glucose rather than fatty acid oxidation and lack key structural features such as transverse tubules (T-tubules) [25, 26]. Indeed, from an epigenetic and transcriptional point of view, hPSC-CMs most closely resemble fetal cardiomyocytes [11, 27, 28]. Improving hPSC-CMs maturation is thereby one of the most ambitious challenges faced by the field today.

Lessons from embryonic development have been pivotal in informing the establishment of methods for the differentiation and maturation of hPSC-CMs [3, 7, 29]. For instance, the study of WNT signaling during early embryogenesis [7, 30] paved the way to methods which rely on biphasic modulation of the WNT pathway to first induce mesoderm (WNT activation) and then specify cardiac progenitors (WNT inhibition [7]). Similarly, the evaluation of hormone levels throughout fetal and postnatal development $[31,32]$ unveiled the role of triiodothyronine (T3) and glucocorticoids in promoting multiple aspects of hPSC-CM maturation [33, 34]. In a similar vein, we submit that the development of scalable and efficient strategies for hPSC-CM maturation will require careful examination of cardiac development during both the late gestational and postnatal periods. However, an updated and comprehensive collection of the available information appears, to the best of our knowledge, to be lacking.

This review addresses this limitation by summarizing our current understanding of the fundamental mechanisms in late gestation and postnatal life that drive the physiological maturation of embryonic cardiomyocytes toward an adult phenotype. We discuss how some of these paradigms have already been implemented to promote hPSC-CM maturation, and we highlight benefits and limitations of current technologies. We conclude by assessing the missing pieces in the cardiac maturation puzzle and by suggesting future areas of research both in vivo and in vitro. Due to its relevance to most current applications of hPSC-CM technology, this review is centered on the ventricular cardiomyocyte subtype.

\section{Gestational Cardiac Development}

Acquisition of the cardiac cell fate is tightly interwoven with the morphogenetic events that underpin the formation of the heart in utero. Throughout this process, a number of changing factors in the extracellular milieu contribute to the first key stages of cardiomyocyte maturation. Unfortunately, gestational maturation has been much less studied than the earlier processes of cell type specification and organ morphogenesis. Furthermore, animal models will not perfectly predict human cardiomyocyte maturation [35, 36], and the scarcity of human samples at this developmental stage limits our understanding human-specific elements of maturation. Here we summarize what we know about this "black box" of cardiac development.

\section{Morphogenetic Events}

The human heart is the first organ to form during embryogenesis. This is a complex, multistep process requiring fine orchestration of different cell populations [37, 38]. During gastrulation, the pluripotent epiblast gives rise to a multilayered structure composed by endoderm, mesoderm, and neuroectoderm [38]. A subset of cells localized in the lateral plate mesoderm gives rise to two main cardiogenic populations named first and second heart field (FHF and SHF). These are organized in a bilaterally symmetric structure detectable at human embryonic development day 18 (E18; E7.5 in mice) [37, 39]. Cells from the FHF migrate and fuse at the midline, generating the primitive heart tube by E20 (E8 in mice) [39]. This structure is composed by an outer layer of myocardial cells, which predominantly contribute to the working myocardium of the left ventricle, and an inner layer of endocardial cells, which develop into the heart valves and the deep coronary circulation [40]. These layers are separated by an acellular hydrophilic matrix named cardiac jelly [40]. This structure contains paracrine signals that drive the epithelial-mesenchymal transition (EMT) of endocardial cells into mesenchymal cells, which then proliferate and invade the cardiac jelly [41]. This process generates the endocardial cushion, which lines the atrioventricular canal and the outflow tract, and is the precursor of heart valves [42]. The slowly differentiating cells from the SHF integrate into the forming heart at the arterial and venous poles, and contribute to the right ventricle, to parts of the left and right atria, and to the outflow tract $[43,44]$. Another population of 
mesodermal cells in the so-called pro-epicardium, localized dorsally to the heart tube, gives rise to epicardial cells [45]. In addition to forming the mesothelial cells that line the heart's outer surface, epicardial cells are precursors of multiple cell lineages that contribute to the generation of the interstitium and the vasculature such as cardiac fibroblasts and coronary vascular smooth muscle cells [46, 47].

The heart's pacemaking centers, the sinoatrial node (SAN), and atrioventricular node (AVN), are another crucial component for the developing heart. Lineage tracing experiments in mouse and chick embryos demonstrated that pacemaker cells arise from a defined lateral plate mesoderm population separated from the FHF and the SHF, suggesting that it constitutes a "tertiary heart field" [48-50]. Cells of the SAN seems to be segregated early in the sinus venosus region of the heart tube under the regulation of T-box (Tbx) transcription factors Tbx 18/Shox $2 /$ Tbx 3 [51]. This cell population has the fastest beating rate and therefore dictates the pace of the entire heart [51]. At this stage, the ECG recording shows a sinusoidal wave, starting from the caudal region and slowly diffusing throughout the heart tube, resulting in peristaltic contraction $[52,53]$. The AVN forms later than the SAN and rises from the crest of the interventricular septum under the control of Tbx3. This transcription factor, together with Tbx18 and Shox2, represses working myocardial genes (Gja5/Cx40, Gjal/Cx43, Nppal ANF, Scn5a/Nav1.5) and promotes expression of Cx30.2 and Hcn channels [51]. The presence of the low-conductance Cx30.2 in these regions delays the propagation of the electrical impulse; indeed, in the mammalian heart, the electrical conductance of $\mathrm{Cx} 30.2$ is $9 \mathrm{pS}$ compared to $162 \mathrm{pS}$ of $\mathrm{Cx} 40$, expressed in the ventricular conduction system [54]. The different expression of gap junctions is crucial for establishing the unidirectional propulsion of the blood flow in the absence of the valves [55]. The His-Purkinje conduction system is derived from a population of working ventricular myocytes expressing $\mathrm{Cx} 40$, but negative for $\mathrm{Tbx} 3$, and is responsible for rapid propagation of the electrical impulse distal to the AVN $[56,57]$. This population remains segregated within the trabecular myocytes during development, as demonstrated in lineage tracing experiments by labeling Gja5/Cx40-expressing cells [56].

Finally, cardiac neural crest cells migrating from the neural tube contribute to cardiac septation by mediating the symmetrical development of the endocardial cushion and the septation of the outflow tract into the pulmonary artery and aorta [58].

During early- and mid-gestational periods, the heart undergoes a number of complex morphological changes. The heart tube can be divided into the truncus arteriosus, bulbus cordis, ventricle, and sinus venosus, as shown in Fig. 1. Starting from E23 and until E35 (E8.5-E10.5 in mice), the straight heart tube gradually transforms into a helically wound structure in a process called cardiac looping [59]. This begins with the movement of the upper portion (truncus arteriosus and bulbus cordis) in a ventral and caudal direction, creating a C-loop shape pointing toward the right side of the embryo (Fig. 1, E24). In the consecutive S-looping phase, the ventricle moves dorsally and cranially, pulling along the atria. During this phase, the distance between the arterial pole and the venous pole shortens, and the ventricular portion shifts below the atrial segment [59]. This process establishes the left-right asymmetry of the future ventricle chambers (and indeed, the first lateral asymmetry in the embryo) and imparts the definitive topological relationship between the different parts of the heart, including the great vessels [59]. After cardiac looping, cardiomyocytes and endocardial cells in the ventricular wall proliferate and form sponge-like structures called trabecular ridges. Trabeculation both facilitates nutrient exchange and enhances contractile force generation in order to respond to the increasing blood and oxygen demands of the developing embryo, due to the lack of coronary vasculatures $[60,61]$. The trabecular ridges are constituted by clusters of cardiomyocytes loosely attached to the compact myocardium and surrounded by endocardial cells [60, 62]. As development proceeds, cardiomyocytes adjacent to the epicardium are characterized by increased proliferation rate, whereas the cardiomyocytes closer to the endocardium are more differentiated [60, 62].

Heart partitioning in the four chambers is due to the formation of the interventricular septum, the interatrial septum, and the atrioventricular valves [63]. Between E35 and E40, the endocardial cushions move toward each other until they fuse to form the primitive interventricular septum, subdividing the right and left atrioventricular canals. The mesenchyme around each canal proliferates and forms the atrioventricular valves [42]. The two atria are subsequently separated by the septum primum and septum secundum, while the blood can flow from the right to the left atria through the foramen ovale, bypassing the pulmonary circulation (Fig. 1). Septation is completed by day E55 (E15.5 in mice), at which point the heart becomes a four-chambered, fully functional organ. During this time, epicardial cells undergo extensive proliferation and migration, to eventually cover the entire embryonic heart by E34 (E11.5 in mice) [45]. From gestational week 8 (E18.5 in mice) and throughout the postnatal period, most of the trabeculae collapse toward the myocardial wall forming a thicker, compact structure [61, 64]. Finally, the myocardial wall further matures in a multilayered spirally organized muscle during neonatal stage (Section II) [64-66]. 


E22

Fig. 1 Human embryonic heart development. The primitive heart tube forms by human embryonic day 22 (E22) and is divided in four different regions: from head to tail, the truncus arteriosus will give rise to the aorta and the pulmonary trunk; the bulbus cordis will develop into the right ventricle; the ventricle region will form the left ventricle and the anterior portion of the right and the left atria; and the sinus venosus develops into the posterior portion of the right atrium, the SA node, and the coronary sinus. By E24, the heart tube starts to bend in a primitive C-shape. Ventricular myocytes undergo

\section{Environmental Dynamics of the Gestational Heart}

The morphological changes happening during heart development are governed both by mechanical forces exerted on the myocardial wall by the blood flow and the availability of energy substrates like oxygen and carbon sources which ultimately affect cardiogenesis on both a cellular and a molecular level.

During the early stage of embryogenesis, the first heart beat in humans can be observed as soon as day E22 (E8 in mice), and this seems to drive the development of primordial hemodynamic forces that eventually will promote cardiac development [67]. In the straight heart tube phase, the blood flow is barely detectable but becomes substantial after cardiac looping, due to the formation of the chambers and the development of coronary vasculature [68]. This results in an increased blood pressure and mechanical strain to which fetal cardiomyocytes are exposed. The blood pressure measured in human fetuses showed a linear increase with advancing gestation, with the left and the right ventricular systolic pressures ranging between 28 and $45 \mathrm{mmHg}$ from the 20th and 40th gestational weeks [67, 69]. trabeculation, whereas the endocardial cells start to migrate into the endocardial cushions. By E28, the heart tube creates a S-shape with the primordial division of the four chambers. By E56, the fetal heart is completely formed; the septa primum and secundum divide the two atria, which remain connected through the foramen ovale, while the endocardial cells from the cushions give rise to the tricuspid and the mitral valves. The dashed line indicates the coronal sections depicted below each stage

Evaluation of mechanical strain across the myocardial wall also revealed an increasing strain gradient from the compact myocardium toward the inner layer of the heart [70]. These differences affect the phenotype of the fetal cardiomyocytes. Cells become elongated and have decreased mitotic activity in the region exposed to increased mechanical forces, like trabecular cardiomyocytes $[60,62,70]$. The formation of the different septa and valves, and the development of the coronary vasculature also modifies the hemodynamic flow within the heart, where laminar blood flow dominates the early fetal stage and turbulent flow becomes predominant during chamber formation. Indeed, wall shear stress increases from 80 to 250 dynes $/ \mathrm{cm}^{2}$ as evaluated in chick embryos between HH23-27 [67].

The role of hemodynamic forces in cardiac development has been demonstrated in a variety of animal models in which blood flow was impaired by either occlusion of the outflow tract [71] or ligation of the left atrium [72]. In these models, manipulation of blood flow resulted in impaired cardiac morphogenesis, with hypoplasia of the left ventricular wall and trabeculae noncompaction $[67,71,72]$. 
Although the precise molecular mechanism by which hemodynamic forces affect cardiomyocytes maturation is still not fully determined, endocardial-myocardial communication seems to control the architecture of the developing heart by expression of different signals, including Notch and neuregulin-1 (NRG1) [61, 73]. Indeed, apical expression of NRG1 promotes trabeculae expansion by increasing extracellular matrix (ECM) synthesis [61, 74]. Vice versa, the expression of the Notch signaling components delta-like canonical Notch ligand-4 and Notch1 intracellular domain (DLL4-N1ICD) at the base of the nascent trabeculae promotes cardiomyocytes proliferation by activating bone morphogenic protein 10 (BMP10) [75] and thus, suppressing the cell-cycle inhibitor $\mathrm{p} 57^{\mathrm{kip} 2}[75,76]$.

The high proliferative rate of early fetal cardiomyocytes is also associated with their predominant metabolic substrate for energy production: glucose. Glycolysis is the catabolic pathway that most efficiently provides the main biosynthetic precursors for macromolecules such as nucleic acids, lipids and proteins, all of which are required at high levels in rapidly proliferating cells [77]. Accordingly, the ventricular wall of fetuses from diabetic mothers show hyperplasia and increased thickening, a feature that is often resolved within months after birth as the exposure to the hyperglycemic intrauterine milieu ends [78]. In the fetus, the abundance of glucose and lactate combined with the paucity of fatty acids (less than $0.1 \mathrm{mM}$ ) and the low oxygen levels favor anaerobic glycolysis over fatty acid $\beta$-oxidation [79, 80]. Indeed, plasma lactate levels in the fetus are $\sim 5 \mathrm{mM}$, compared to approximately $0.5 \mathrm{mM}$ in the adult [81]. Such high levels of lactate repress fatty acid $\beta$-oxidation via the so-called Randle Cycle, also known as the glucose/fatty acid cycle [79]. As a result, more than $80 \%$ of ATP produced by fetal cardiomyocytes comes from glycolysis [79]. The anaerobic metabolism of fetal cardiomyocytes is also favored by the expression of specific glycolytic enzymes [82]. In the late stages of pregnancy, the expression of transcripts related to fatty acid oxidation markedly increases [82]. Thus, during this late fetal stage the metabolism starts to switch to become less dependent on glucose and more favorable for fatty acid oxidation. The mechanism that regulates this metabolic switch is still largely unknown, but repression of HIF1 signaling represents a valid candidate for future investigation, due to its role in the regulation of both energy metabolism and cell proliferation [83-85]. Interestingly, there is a gradient of VHL/HIF1 expression from the compact myocardium (high expression) toward the trabecular myocytes (low expression) [85]. This could correlate with the increased proliferation, decreased differentiation, and reduced mitochondrial oxidative activity observed in the compact myocardium.

\section{Postnatal Cardiac Development}

\section{Environment of the Postnatal Heart}

The transition from the intrauterine to extrauterine life is arguably the most complex adaptation that occurs in human experience. At birth, the loss of the placenta deprives the fetus of an important source of energy substrates and hormones. The removal of the umbilical cord and the recruitment of the lungs, together with the exposure of the newborn to a relatively cold environment trigger both physical and endocrine signals in order to ensure the survival in the postnatal life [31, 32, 80, 86].

Cortisol represents one of the major regulatory hormones responsible for neonatal adaptation [32]. Indeed, during fetal life in human, plasma cortisol is very low but it gradually starts to increase around late gestational period (it ranges from 2 to $50 \mu \mathrm{g} / \mathrm{dL}$ in preterm infants [87]) and reaches a peak at labor, with levels four times higher compared to that of gestational stage [86]. This results in the maturation of the lungs associated with the clearance of fetal fluid, activation of thermogenesis as well as metabolic adaptation. Moreover, the expression of mitochondrial membrane protein UCP1 (uncoupling protein1) increases and, together with the boost in catecholamine secretion, thermogenesis is initiated in the brown adipose tissue [88]. Cardiomyocyte maturation is also promoted by glucocorticoids as demonstrated in vivo by administration of betamethasone to preterm piglets [89]. Indeed, treatment with glucocorticoids 24 and $48 \mathrm{~h}$ before delivery increases the number of binucleated cardiomyocytes in piglets, characterized also by reduced proliferation capability [89]. At the molecular levels, cortisol influences these processes potentially by increasing the expression of peroxisome proliferator-activated receptor PPAR- $\gamma$ coactivator $(\mathrm{PGC} 1 \alpha)[90]$. PGC1 $\alpha$ indeed acts as a coactivator for a variety of transcription factors involved in different biological responses such as thermogenesis, mitochondria biogenesis and metabolic control [91].

Thyroid hormones (TH) signaling in the fetus starts to be detectable only at 35-40 weeks of gestation. During fetal life, the thyroid receptor system is completely developed by the 12th gestational week, however the serum concentration of $\mathrm{T} 3$ and $\mathrm{T} 4$ are very low until the hypothalamus-pituitary-thyroid gland axis becomes fully functional [31]. Maternal thyroid hormones have limited ability to cross the placental barrier, indeed placental expression of type 3 iodothyronine monodeiodinase deactivates both $\mathrm{T} 4$ and T3 to their inactive counterparts [31,92]. At birth, the amount of thyroid hormones dramatically increases to peak at high levels of about $300 \mathrm{ng} / \mathrm{dL}$ for T3 [31], $12 \mu \mathrm{g} /$ $\mathrm{dL}$ for T4 as well as an eightfold increase of TSH levels [92]. This increase could be triggered by both the surge in 
cortisol [86] and the acquisition of homeothermy with the initiation of thermogenesis [31, 92]. The effects of thyroid hormones are mainly due to the activation of thyroid hormone receptors (THR $\alpha$ and THR $\beta$ ), expressed in the nucleus of the cells but also could be exerted by the $\alpha \mathrm{v} \beta 3$-mediated integrin signaling $[31,93]$, although this pathway is still not investigated in cardiomyocytes [94]. TH modulates cardiomyocytes inotropic maturation by modulating the expression of calcium handling and sarcomere proteins, and induces a hypertrophic response by increasing cell size [31, 94, 95]. The spike in TH at birth is also associated with cardiomyocytes cell-cycle withdrawal [31]. Indeed, cardiomyocytes with impaired TH signaling showed increased proliferation and decreased polyploidization [96]. Moreover, TH seems to control the expression of Glut 1 and Glut 4 during rat heart development. These two glucose transporters are differentially regulated during development, with GLUT1 highly expressed in the fetal stage, whereas GLUT4 becomes the main glucose transporter in the adult stage $[80,97]$. Translocation of GLUT4 to the cytoplasmic membrane is regulated by insulin, whereas GLUT1 constitutively localizes to the plasma membrane once it is synthesized, independent of insulin. Administration of T3 to hypothyroid rats showed increased expression of Glut4 combined with decreased levels of Glut 1; thus, indicating a TH involvement in postnatal metabolic adaptation [97].

Circulating catecholamines, i.e., noradrenaline, adrenaline and dopamine increase up to tenfold at birth, due to both the maturation of adrenal medulla and the loss of placental clearance of catecholamines [86]. Cardiomyocytes' responsiveness to adrenergic stimuli is already present in fetal cardiomyocytes, although $\beta$-adrenergic stimulation results only in increased chronotropism without inotropic effects, potentially due to the low number of receptors and the absence of phospholamban, an adrenergic-responsive regulator of SERCA2a activity $[98,99]$. This catecholamine surge participates in postnatal cardiac adaptation by increasing blood pressure and cardiac inotropic effects; it also is involved in metabolic switching by mediating glucagon secretion and decreasing insulin secretion as well as induction of thermogenesis [86, 92].

Insulin-like growth factor-1 (IGF-1) is an anabolic hormone that is involved in regulation of proliferation, differentiation and postnatal growth of the fetus. This hormone is supplied to the fetus from the placenta during early gestation, and it increases during the last trimester due to secretion from the fetal liver [100]. Indeed, IGF-1 increases from $40 \mu \mathrm{g} / \mathrm{L}$ at 18 th gestational week to almost $160 \mu \mathrm{g} / \mathrm{L}$ at birth [101]. Circulating levels of IGF-1 are regulated by growth hormone $(\mathrm{GH})$ and insulin at both transcriptional and posttranscriptional levels [101]. These three hormones are essential for metabolic homeostasis; indeed, they regulate nutrient availability in order to provide adequate substrates for growth [80, 102]. Insulin per se promotes fetal growth by enhancing the cellular uptake of glucose and potentially other energy substrates, like amino acids. Fetal pancreatectomy in sheep results in a significant decrease in glucose uptake and oxidation and 30\% decrease in fetal growth; conversely, high fetal insulin levels (such as from maternal diabetes) are associated with increased body weight [78, 103]. Accordingly, rat cardiomyocytes treated with insulin increased plasma membrane expression of the fatty acid transporter $\mathrm{Cd} 36$ and Glut 4 , with a subsequent decrease in their localization in the microsomal fraction [104]. Growth hormone controls fetal development by stimulating hepatic release of IGF-1; excess production of GH (acromegalic cardiomyopathy) or decreased levels of GH (GH deficiency) both result in cardiac developmental defect [105]. IGF-1 stimulates protein synthesis by modulating the PI-3 kinase/ mTOR pathway, and it also regulates free fatty acid utilization in skeletal muscles, potentially via modulation of Cd36 [106]. In vitro studies on neonatal rat cardiomyocytes demonstrated that IGF-1 treatment increases maturation of contractile apparatus as well as induces hypertrophy [107].

Postnatal adaptations are also mediated by air breathing, which induces the closure of the ductus arteriosus and the foramen ovale, along with marked vasodilation of the pulmonary vasculature, resulting in a low-pressure pulmonary circulation, a higher pressure systemic circulation and near$100 \%$ oxygenation of hemoglobin [108]. Indeed, the oxygen tension in the fetal circulation is only $25-28 \mathrm{mmHg}$, as evaluated in ascending aorta of fetal lamb [109]; this is due to the presence of the different shunts resulting in the mixing of arterial and venous blood [109].

On a tissue levels, the paracrine signals secreted by fibroblasts, endothelial cells and smooth muscle cells also modulate cardiomyocyte postnatal maturation $[110,111]$. These stromal-vascular cells encounter almost $70 \%$ of the total cell population present in the heart and likely contribute to cardiac maturation [110], although we know much less about these interactions. Notably, fibroblasts from the fetal and the neonatal or adult heart secrete different signals [111]. Co-culture of embryonic cardiomyocytes and embryonic fibroblasts from E12.5 to E13.5 mouse embryos stimulate cardiac proliferation due to fibroblast-secreted fibronectin, collagen, and heparin-binding EGF-like growth factor. Conversely, when these same cardiomyocytes are co-cultured with adult fibroblast, the proliferative effect is replaced by a hypertrophic response [111]. This hypertrophic signaling seems to be mediated by increased expression of interleukin-6 (Il6) in the adult fibroblast (58-fold higher compared to the embryonic fibroblast), whereas ECM/ $\beta 1$-integrin signaling is required for cardiomyocytes proliferation in response to growth factors [111]. Accordingly, fibroblasts could be detected at E12.5 (mice) and this is associated with 


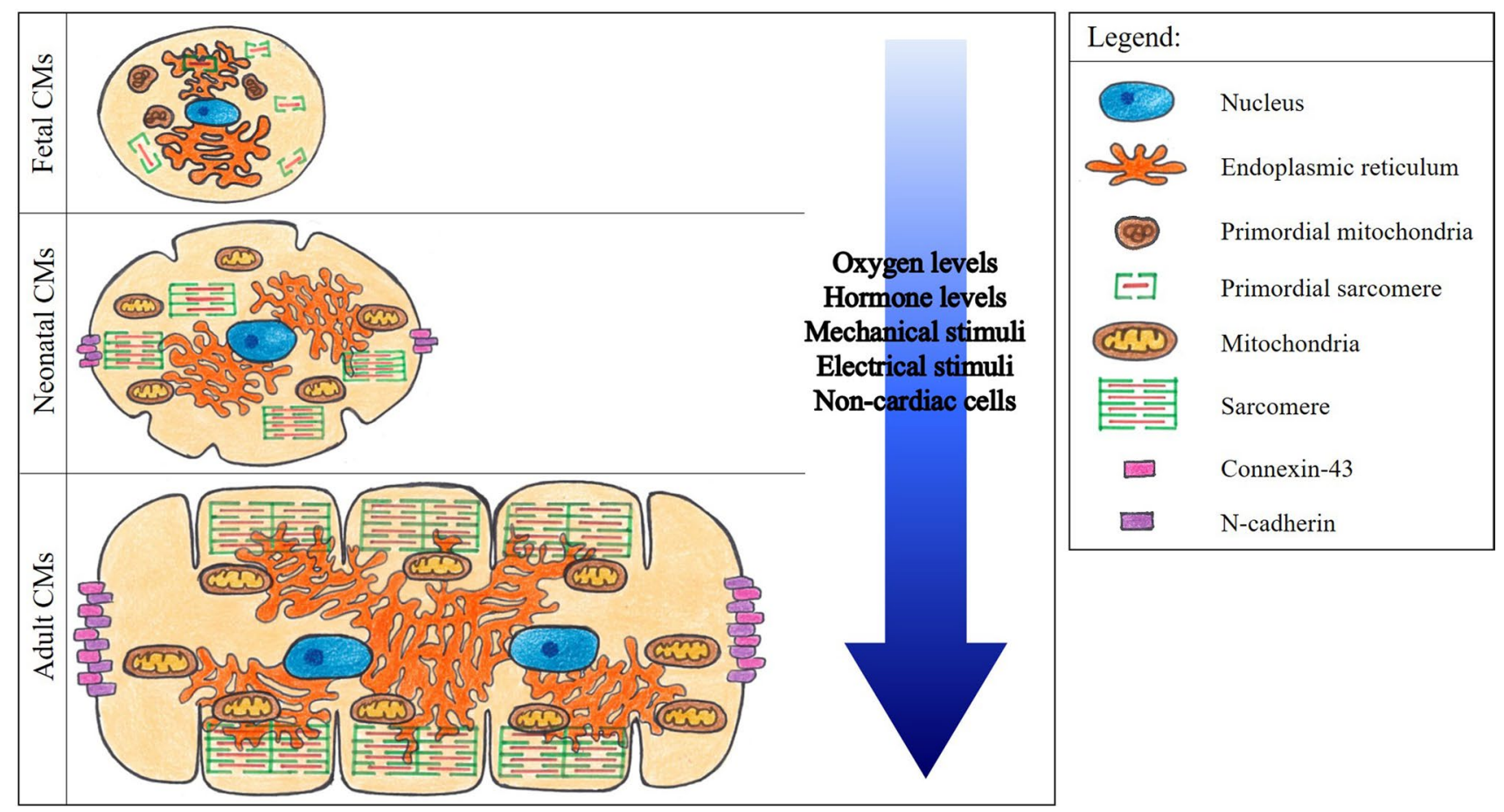

Fig. 2 Cardiomyocyte maturation. Fetal cardiomyocytes (CMs) are small and round-shaped, with undeveloped mitochondria and sarcomeres. Multiple environmental cues, such as mechanical and electrical stimuli, extracellular matrix interactions, and interactions with noncardiomyocytes drive gradual maturation of CMs. Through neona-

increased ECM synthesis, upregulation of $\beta 1$ integrin and increased cardiomyocytes proliferation [111].

Postnatal cardiac adaptation results in a linear increase of cardiac output from $120 \mathrm{~mL} / \mathrm{min}$ at $15-20$ weeks of gestation to $1700 \mathrm{~mL} / \mathrm{min}$ at birth, and finally to $5000 \mathrm{~mL} / \mathrm{min}$ in the adult [112]. The surge in the afterload and preload, together with increasing levels of circulating vasoactive molecules, increase the left ventricular systolic pressure, which rises from approximately $30 \mathrm{mmHg}$ during gestation, to $75 \mathrm{mmHg}$ at birth, reaching $90 \mathrm{mmHg}$ at 1 year of age [67, $69,86,113]$. This increased workload is accompanied by the physiological enlargement of the left ventricular chamber, with $\mathrm{LV}$ end-diastolic volume increasing from $1.4 \mathrm{~mL}$ at 36 weeks of gestation [114] to $2.6 \mathrm{~mL}$ in the early neonatal period ( 5 days after birth) and to $150 \mathrm{~mL}$ in the adult human [115].

Overall, changes in endocrine factors, oxygen tension, hemodynamic forces, and the phenotype of noncardiac cells are the key extracellular signals marking the end of the fetal stage and driving postnatal cardiomyocyte maturation (Fig. 2). In the next section, we discuss the main cellular modifications triggered by such signals. tal and adult stages, CMs become elongated and display increased cytoskeletal organization. Expressions of Connexin-43 and N-cadherin increase, and mitochondria develop mature cristae. Adult CMs are also often binucleated and display robust T-tubules and intercalated disks

\section{Electrical Activity of Postnatal Cardiomyocytes}

Early fetal cardiomyocytes differ substantially from their adult counterparts in terms of their electrophysiological properties, particularly with regards to automaticity (the ability to periodically and spontaneously depolarize until an action potential is triggered). As reviewed above, while automaticity is restricted to specialized cardiomyocytes in the adult heart, all early fetal cardiomyocytes show strong automaticity $[49,56]$.The precise molecular basis of cardiac automaticity is still being debated. Two main nonexclusive mechanisms have been described: (1) the "voltage clock," constituted by a slow, inward sodium current mediated by the hyperpolarization-activated cyclic nucleotide-gated channels encoded by the $H C N$ gene family (the so-called "funny current," $I_{\mathrm{f}}$ ); and (2) the "calcium clock," initiated by calcium leaks from the sarcoplasmic reticulum (SR) through the ryanodine receptor (RYR2), which lead to activation the sodium-calcium exchanger (NCX) and result in a net depolarizing current (as three $\mathrm{Na}^{+}$are imported for each exported $\mathrm{Ca}^{2+}$ ). The progressive resting membrane potential depolarization resulting from these clocks may be further amplified by voltage-dependent T-type calcium channels ( $I_{\mathrm{CaT}}$, encoded by CACNAIG, CACNAIH, and CACNAII) $[116,117]$. Of note, while the role of these ion channels in 
Table 1 Features of developing CMs versus hPSC-CMs

\begin{tabular}{|c|c|c|c|c|}
\hline Parameters & Fetal $\mathrm{CMs}^{\mathrm{a}}$ & Neonatal $\mathrm{CMs}^{\mathrm{a}}$ & hPSC-CMs $(<30$ days in culture $)$ & Adult-CMs ${ }^{\mathrm{a}}$ \\
\hline \multicolumn{5}{|l|}{ Morphology } \\
\hline Surface area & $1216 \pm 44.6 \mu \mathrm{m}^{2}[193]$ & $4395 \pm 436 \mu \mathrm{m}^{2}[194]$ & $1000-1300 \mu \mathrm{m}^{2}[193]$ & $12,315 \pm 2103 \mu \mathrm{m}^{2}[194]$ \\
\hline Capacitance & $20.3 \pm 4.6 \mathrm{pF}[231]$ & NA & $24.6 \pm 3.3 \mathrm{pF}[231]$ & $100-150 \mathrm{pF}[195]$ \\
\hline Length-to-width ratio & 5:1 (mouse) [149] & 5:1 (mouse) [149] & $2: 1[27]$ & $7-9.5: 1[197]$ \\
\hline \multicolumn{5}{|l|}{ Contractility } \\
\hline Sarcomere length & $1.2 \mu \mathrm{m}$ (piglet) [89] & $1.95 \mu \mathrm{m}$ (rat) [232] & $1.6 \mu \mathrm{m}[209]$ & $2.2 \mu \mathrm{m}[26]$ \\
\hline Force production [201] & $0.4 \mathrm{mN} / \mathrm{mm}^{2}$ & $1.2 \mathrm{mN} / \mathrm{mm}^{2}$ & 0.1 to $0.5 \mathrm{mN} / \mathrm{mm}^{2}$ & $10-50 \mathrm{mN} / \mathrm{mm}^{2}$ \\
\hline \multicolumn{5}{|l|}{ Isoform [26] } \\
\hline Titin & N2BA & N2BA & N2BA & $\mathrm{N} 2 \mathrm{~B}$ \\
\hline MHC & $\alpha$ & $\alpha$ & $\alpha$ & $\beta$ \\
\hline Troponin & ssTnI & ssTnI & ssTnI & cTnI \\
\hline \multicolumn{5}{|l|}{ Electrophysiology } \\
\hline RMP [202, 203] & $-40 \mathrm{mV}$ & $-60 \mathrm{mV}$ & $-40 \mathrm{mV}$ & $-85 \mathrm{mV}$ \\
\hline$I_{\mathrm{f}}$ & $-7 \mathrm{pA} / \mathrm{pF}$ (mouse) [123] & $-3.5 \mathrm{pA} / \mathrm{pF}$ (mouse) [123] & $-4.1 \mathrm{pA} / \mathrm{pF}[203]$ & $-1.9 \mathrm{pA} / \mathrm{pF}[125]$ \\
\hline$I_{\mathrm{CaT}}[202]$ & $-4 \mathrm{pA} / \mathrm{pF}$ (mouse) & $-2 \mathrm{pA} / \mathrm{pF}$ (mouse) & Present & Absent \\
\hline$I_{\mathrm{CaL}}[202]$ & $-6 \mathrm{pA} / \mathrm{pF}$ (mouse) & $-8 \mathrm{pA} / \mathrm{pF}$ (mouse) & $-6 \mathrm{pA} / \mathrm{pF}$ & $-9 \mathrm{pA} / \mathrm{pF}$ \\
\hline$I_{\mathrm{K} 1}$ & $6-8 \mathrm{pA} / \mathrm{pF}$ (mouse) [131] & $6-8 \mathrm{pA} / \mathrm{pF}$ (mouse) [131] & Absent [26] & $12 \mathrm{pA} / \mathrm{pF}[233]$ \\
\hline Metabolism [26] & Glycolysis & Glycolysis & Glycolysis & FA OX \\
\hline
\end{tabular}

${ }^{a}$ Unless indicated otherwise, all parameters are reported for human cardiomyocytes

regulating the pacemaking activity of the postnatal heart is supported by studies in animal models and by clinical evidence [118, 119], whether these same mechanisms mediate automaticity in the early embryonic heart is still largely unknown $[117,120]$.

The expression of HCN4 in the working myocardium gradually decreases during development, and this channel is virtually absent at human postnatal day 37 (Table 1) [121, 122]. In ventricular mouse cardiomyocytes, the amount of inward current that flows through Hen 4 is $\sim 7 \mathrm{pA} / \mathrm{pF}$ at day E10.5, and decreases by 50\% at day E16.5 [123]. In humans, HCN4 and T-type calcium channels are still detectable in neonatal ventricular cardiomyocytes, which could explain their retained automaticity and the heart rate variability in the first week after birth $[123,124]$. In contrast, in the human adult working myocardium, the amount of funny current is only $1.9 \mathrm{pA} / \mathrm{pF}$ [125]. In agreement with its key function in calcium and sodium homeostasis during the cardiac cycle, expression of NCX increases linearly during embryogenesis and is highest at the fetal stage (19th week of gestation). Interestingly, during postnatal and adult stages, the levels of NCX mRNA are lower compared to that of fetal stage. However, the ratio of protein level to mRNA level is higher in the adult, indicating that NCX is subjected to substantial posttranscriptional regulation [116, 126, 127]. In E12.5 mouse embryos, calcium release from the SR is dependent on the inositol 1,4,5-triphosphate receptor (Itpr3) [128]. From mouse E16.5 onward, calcium release is mediated by the increasing levels of Ryr2, which mediates localized
$\mathrm{Ca}^{2+}$-induced-Ca ${ }^{2+}$-release in the proximity of T-tubules due to its association with the L-type calcium channels [128, 129]. This more refined regulation of intracellular calcium levels leads to increased action potential amplitude and duration [130]. The expression of SERCA2a, which pumps calcium from the cytosol into the sarcoplasmic reticulum, linearly increases during development. Interestingly, levels of the SERCA $2 a$ mRNA do not substantially change between embryonic, fetal, neonatal, and adult stages, but SERCA2a protein levels largely increase during cardiac maturation, indicating the existence of posttranscriptional regulation also for this factor [116, 131].

The expression of ion channels involved in cardiac automaticity is thought to be regulated by regionally expressed transcription factors like Nkx2.5, Shox 2 and T-box transcription factors [121]. Tbx3 is detectable only in the pacemaker progenitors cells and in the conduction system, and its ectopic expression in the working myocardium of mice leads to upregulation of Hcn1, Hcn2, Hcn4, and Cacnalg $[56,121]$. On the contrary, Nkx2.5 represses the expression of these pacemaking ion channels, possibly via the inhibition of Shox 2 [121, 132]. In addition, the presence of a conserved binding site for the transcriptional repressor NSRF (also known as Rest) in the first intron of Hcn4 could also modulate its expression [133]. NSRF is a transcriptional repressor that acts through the recruitment of class I and class IIa histone deacetylases (HDACs). It is highly expressed in ventricular cardiomyocytes from 20-weekold mice compared to those from embryos at E13.5 [133]. 
NSRF is potentially involved also in the regional expression of T-type calcium channels (Cacnalg and Cacnalh), whose expression decreases over time and becomes undetectable in the adult working myocardium [131, 133, 134].

Another hallmark of cardiac maturation is the decrease in the resting membrane potential, which for ventricular myocytes shifts from -40 to $-70 \mathrm{mV}$ in the fetal stage (E12-E18 in mice) to $-85 \mathrm{mV}$ in the adult [135]. The stabilization of the resting membrane potential at a hyperpolarized level further decreases the automaticity of the working myocardium. This process is predominantly controlled the inwardly rectifier potassium current $I_{\mathrm{K} 1}$, which is mediated by the Kir 2.1 channel encoded by the KCNJ2 gene. In the mouse, expression of Kir 2.1 is first detectable at E17.5, begins to increase at $\mathrm{P} 1$, and is strongly upregulated only 5 to 8 weeks after birth (Table 1) [127, 131]. This increase could be potentially related to the action of the Notch-responsive transcription factor Hey2, which is also involved in cardiac morphogenesis and ventricular cardiomyocyte terminal differentiation [136, 137].

In summary, the electrical activity of the postnatal heart is determined by the regional and temporal regulation of transcription factors that are expressed throughout the myocardial wall and gradually become restricted to specialized area starting from the 5 th week of gestation (E12.5 in mice) and through the postnatal period [57].

\section{Structural Organization of Postnatal Cardiomyocytes}

Cardiomyocytes undergo extensive structural changes during the postnatal period. Many of the proteins required for sarcomere formation and cytoskeletal organization are already expressed when the heartbeat begins at E22 (E8 in mice), but at lower levels or in different isoforms compared to the adult (Fig. 2) [138]. A prominent example is titin, the largest human protein, which spans from the Z-disk to the M-line and is responsible for both sarcomere assembly and integrity. During development titin is expressed in multiple isoforms as a result of alternative splicing, a process controlled by the cardiac-specific splicing regulator RBM20 [139, 140]. The fetal isoform N2BA switches to the less compliant N2B isoform soon after birth, resulting in increased passive tension at a given sarcomere length [139]. This augments myocardial stiffness, thereby compensating for the large increase in the end-diastolic volume of the left ventricle, which increases up to 100 -fold from late gestation stage [114] to the adult stages in humans [115], as discussed in the previous section. Myosin heavy chain (MHC) isoforms in human also switch from $\alpha-\mathrm{MHC}$ to $\beta$-MHC, leading to slower ATPase activity and stronger actin binding, both of which are important for stronger contractions at slower heart rates [141]. Conversely, in rodents, myosin isoform switches from $\beta$ to $\alpha$ postnatally, which accommodates the 3- to fourfold increase in mouse heart rate postnatally $[142,143]$. Regulatory troponin I (TnI) is initially present as the slow skeletal TnI (ssTnI) isoform, and after birth it switches to the cardiac isoform (cTnI) [138, 144]. This is associated with an increase in myofibrillar sensitivity to $\mathrm{Ca}^{2+}$, promoting stronger contractions soon after birth (Table 1) [145].

Besides mature sarcomeres, efficient excitation-contraction coupling (E-C coupling) and fast conduction rely on two structures that are detectable only in adult cardiomyocytes: the T-tubules and the intercalated disks. T-tubules are plasma membrane invaginations along the $\mathrm{Z}$-line regions, which carry sarcolemmal ion channels deeply into the cell and allow juxtaposition with the sarcoplasmic reticulum [26]. Intercalated disks are cardiac-specific cell-cell junctional complexes containing desmosomes, intermediate junctions and gap junctions that together allow rapid transmission of contractile forces and electrical signals within cardiomyocytes [146]. Primordial T-tubules and intercalated disks are already detectable in the human fetus, but fully mature structures are not complete until age 7 [147-149]. T-tubulation requires the expression of developmentally regulated membrane proteins like caveolin-3 [150], whose expression strikingly increases after birth [95], as well as the expression of bridging integrator-1 [151] and junctophilin-2 [152]. The formation of intercalated disks dictates the structural anisotropy of the adult cardiomyocyte as it leads to the characteristic rod-shape and polarity. Indeed, the strong polarization of Connexin-43 and $\mathrm{N}$-cadherin in adult cardiomyocytes determines a length-to-width ratio of 7 to 9.5. Conversely, the lower abundance and circumferential distribution of these structural proteins in neonates results in a length-to-width of $\sim 5[66,149]$. Maturation also leads to progressive myofibril polarization: in mice their orientation (evaluated as the angle difference made by the myofibril compared to the longitudinal axis) is of 6.14 at E18.5 compared to 5.00 at P4 [149], indicating increased alignment.

Collectively, changes in calcium handling proteins, formation of T-tubules and intercalated disks, improved sarcomere organization, and changes in myofibril protein isoforms largely improve the efficiency of $\mathrm{E}-\mathrm{C}$ coupling and increase the myofilament sensitivity to calcium, leading to greatly increased contractility [153]. As a result, the contractile force of human ventricular myocardium goes from $\sim 0.4$ $\mathrm{mN} / \mathrm{mm}^{2}$ in the fetus to $\sim 1.1 \mathrm{mN} / \mathrm{mm}^{2}$ in the neonate, and finally to $10-50 \mathrm{mN} / \mathrm{mm}^{2}$ in the adult $[154,155]$.

\section{Metabolism of Postnatal Cardiomyocytes}

The adult heart is one of the most energy-consuming organs of the body, followed by the kidney, the brain, and the liver [156]. Indeed, the ATP consumption of a healthy adult heart is around $30 \mu \mathrm{mol} / \mathrm{min}^{-1}$ per gram of tissue 
at rest [157]. Because of the relative shortage of energy reserves (ATP is found at $\sim 5 \mathrm{~mol} / \mathrm{g}$ of heathy cardiac tissue [158]), the heart must continuously produce high amounts of energy. In the adult, more than $80 \%$ of ATP production is the result of fatty acid $\beta$-oxidation in the mitochondria $[158,159]$. In contrast, as introduced in Section I, the preferential metabolic pathway in the embryo and fetus is glycolysis (contributing to more than $80 \%$ of all ATP) [77, 80, 160]. After birth, the increasing energy demand of the growing body combined with new availability of carbon substrate (feeding on lipid-rich milk) and arterial oxygen rapidly converts metabolism from anaerobic glycolysis to fatty acid oxidation $[160,161]$. Whereas levels of fatty acids are less than $0.1 \mathrm{mM}$ in the fetus, they increase immediately after birth to $\sim 0.4 \mathrm{mM}[80]$. Moreover, the $\mathrm{PaO}_{2}$ increases from $\sim 28$ to $\sim 100 \mathrm{mmHg}$ in the postnatal stage $[108,109]$. Such an increase in oxygen levels is required for efficient fatty acid $\beta$-oxidation [162], as the oxidation of one gram of palmitate requires 2.4-fold more oxygen than a gram of glucose (with commensurately greater ATP yield). Fatty acid $\beta$-oxidation is also favored by the postnatal expression of different metabolic enzymes. As the newborn develops, the ATP consumption in the heart rises continuously, and this energy depletion activates the energy-sensing enzyme, AMP-kinase (AMPK), which contributes to the metabolic switch toward fatty acids' utilization by inhibiting acetyl-CoA carboxylase (ACC) [163, 164]. Indeed, ACC is highly expressed in the fetal and early postnatal periods but decreases dramatically within days after birth [165]. ACC produces malonyl-CoA, which in turn inhibits the activity of CPT1, a transporter required for lipid trafficking across the mitochondrial membrane. The activity of ACC is further inhibited by malonyl-CoA decarboxylase (MCD), which, like AMPK, is also more active postnatally [164]. Overall, the decreased expression and activity of ACC after birth improves CPT1 function, leading to increased mitochondrial lipid uptake.

The mitochondria themselves also become more functional postnatally due to both increased biogenesis and structural remodeling, which facilitates energy production and its transfer to the myofibrils and sarcoplasmic reticulum [166]. Neonatal mitochondria are small, lack fully developed cristae, and have a low transmembrane potential $[135,166]$. The fusion and fission of mitochondria are the key processes that underlie mitochondria biogenesis and maturation [167], and are controlled by different factors that are highly dynamic after birth [168-170]. Among them, the transcriptional coactivators PGC- $1 \alpha$ and PGC- $1 \beta$ regulate mitochondrial biogenesis in the postnatal heart. In particular, PGC-1 controls genes involved in mitochondrial fusion, such as the mitochondrial dynamin-like GTPase OPA1 and mitofusin 1 and 2 (MFN1 and MFN2), and genes involved in mitochondrial fission like dynaminrelated protein 1 (DRP1) and mitochondrial fission protein 1 (FIS1) $[168,169]$. The considerable amount of highenergy phosphates produced by the adult mitochondria is transferred to the myosin ATPase by the phosphocreatine shuttle [171]. This facilitated diffusion system is present only in the postnatal stage due to the increased cytoskeletal organization, and it is highly efficient compared to the simple diffusion mechanisms which dominates the fetal stage.

Overall, the increased energy demand of the postnatal heart is addressed by the metabolic switch from glycolysis to oxidative phosphorylation that, combined with mitochondrial development and a more refined energy transfer system, leads to a highly efficient coupling between energy production in the mitochondrion and utilization at the myofibril.

\section{Cell-Cycle Regulation in Postnatal Cardiomyocytes}

The final stage of cardiac growth, sometimes called terminal differentiation, is marked by a transition from hyperplasia to hypertrophy. DNA synthesis during murine heart development (as evaluated by tritiated thymidine incorporation) occurs in two temporally different phases: there is high DNA synthesis rates in the embryo, e.g., $33 \%$ at E12, which drops to almost undetectable levels at birth [172]. In the early neonatal stage, a second wave of DNA synthesis occurs as the cells become binucleated, with a peak labeling of $10 \%$ at postnatal day P4-6. After postnatal day 10 (P10), DNA synthesis is again almost undetectable [172]. In humans, cardiomyocyte cell-cycle withdrawal is considerably slower: in the first decade of life, $0.01 \%$ of cardiomyocytes were in the mitotic phase; this percentage decreased significantly during adolescence (10-20 years) and it is barely detectable in the hearts of 40 years-old subjects [173-176]. The vast majority of both human and rodent cardiomyocytes undergo a final round of DNA synthesis without mitosis, resulting in polyploid cells [172, 175, 176]. Although the evolutionary basis for polyploid cardiomyocytes is unknown, it may be that the 20-fold myocyte enlargement that occurs during hypertrophic growth requires multiple genomes to achieve [177]. Interestingly, polyploidy is achieved in different ways by different species. In humans, cardiomyocytes undergo DNA synthesis without nuclear division, resulting in $\sim 75 \%$ of cardiomyocytes having polyploid nuclei [175]. In rodents, cardiomyocytes undergo both DNA synthesis and nuclear division but do not undergo cytokinesis. This results in $>90 \%$ of adult rodent cardiomyocytes being binucleated, with each nucleus containing a diploid chromosomal content [172].

Cell-cycle progression is mediated by complexes of cyclins and cyclin-dependent kinases (CDK) like Cyclin E, $\mathrm{D}$, and $\mathrm{A}$, which mediate the progression through $\mathrm{G} 1$ to $\mathrm{S}$, 
and Cyclin A and B, which are responsible for the progression from M to G2. The expression and activity of such complexes is developmentally controlled, and reflects the distinct proliferative states of the developing heart [177]. The expression of these cell-cycle regulators is controlled by transcription factors such as the E2F family and Tbx 10 , which promote expression of cyclins and CDKs, whereas BTG2 and MEIS1, which are significantly upregulated in cardiomyocytes soon after birth, act as negative regulators [177-179]. Other transcription factors like SOX6, GATA4, and MEF2C affect cell proliferation by modulating the PI3K/ AKT, WNT/ $\beta$-catenin, and Hippo-YAP pathways [177, 180-182].

Amongst all of these regulators, the Hippo-YAP pathway has emerged as a major player in mediating cell-cycle withdrawal in cardiomyocytes [182, 183]. Evidence began to accumulate when multiple miRNAs were identified that enhance neonatal rat cardiomyocyte reentry in vitro and adult heart regeneration in vivo [184]. These subsequently were shown to target members of the Hippo pathway for degradation [185]. Genetic inhibition of the Hippo pathway induces cardiomyocyte hyperplasia in fetal mice, in part through unrestrained $\beta$-catenin signaling [186]. Genetic inhibition of Hippo in the adult heart induces cardiomyocyte cell-cycle re-entry [187], and when inhibited after myocardial infarction, this induces cardiac regeneration and improvement in cardiac function [188]. Thus, manipulation of the Hippo pathway has been the most successful means to re-induce division in cardiomyocytes. Conversely, activating this pathway seems to be an important step in postnatal maturity.

Oxygen has been proposed as another key regulator of cell-cycle withdrawal in postnatal cardiomyocytes. For instance, the elevated regenerative capacity of certain amphibians and fish correlates with their relatively hypoxic habitat $[189,190]$. Conversely, the exposure to a hyperoxic environment after birth leads murine cardiomyocytes to exit the cell cycle, possibly through increasing concentration of reactive oxygen species (ROS) and subsequent oxidative DNA damage [190].

In summary, postnatal cues at the cellular, tissue, and organ levels drive cardiomyocyte maturation to the adult phenotype (Fig. 2). Taken together, this suggest that a similar multifaced approach will be required to increase the maturation of stem cell-derived cardiomyocytes.

\section{The Peter Pan Syndrome of Pluripotent Stem Cell-Derived Cardiomyocytes}

Despite substantial process, current approaches to increase the maturation of hPSC-CMs in vitro only manage to produce cardiomyocytes with an intermediate or late fetal phenotype (Table 1) [8, 25, 26]. This contrasts markedly with results from cell transplantation, when cardiomyocytes undergo almost complete structural and molecular maturation in rodent [191, 192], guinea pig [18] or nonhuman primate hearts $[19,22]$. Thus, there is no intrinsic block to maturation in hPSC-CMs. The maturation impediment results from the inability of our in vitro systems to mimic faithfully their natural environment.

The surface area of hPSC-CMs generated by conventional protocols is in the range of $1000-1300 \mu \mathrm{m}^{2}$ [193], close to that of fetal CMs $\left(1216 \pm 45 \mu \mathrm{m}^{2}\right.$ [193]). On the other hand, the surface area for neonatal CMs and adult CMs is $4395 \pm 436 \mu \mathrm{m}^{2}$ and $12,315 \pm 2103 \mu \mathrm{m}^{2}$, respectively [194]. In line with these size differences, the membrane capacitance of hPSC-CMs is $17.5 \pm 7.6 \mathrm{pF}$ [26], which is ten times lower compared to that of adult CMs $(100-150 \mathrm{pF})[26$, 195]. hPSC-CMs are also relatively flat, polygonal to roundshaped, and have an irregular morphology: The length-towidth ratio of these cells ranges from 2 to 4 [196], which is substantially different to that of adult CMs $(7.7-9.5$, as evaluated in isolated human adult CMs [197]). The contractile force generated by hPSC-CMs ranges from 0.1 to $4 \mathrm{mN} /$ $\mathrm{mm}^{2}$ [198-201], depending on the condition in which the force was measured, but it still significantly lower than that of adult CMs (10-50 mN/mm ${ }^{2}$ [155, 201]).This difference may be explained by reduced myofibril content, myofibril disarray and sarcomeric immaturity: ultrastructural analysis revealed that hPSC-CMs have immature sarcomeres in which only the $\mathrm{Z}$ band is sometimes visible, whereas the I-band, A-band, and M-band are absent [27]. Moreover, the expression of fetal isoforms of titin (N2BA), troponin I (ssTnI), and myosin heavy chain ( $\alpha$-MHC), the absence of T-tubules and poor polarization of the intercalated disks, combined with the low expression of RYR2 and SERCA2a collectively lead to inefficient E-C coupling [26, 28, 202]. hPSC-CMs are also characterized by strong automaticity and significantly depolarized resting membrane potential (RMP), which ranges from -50 to $-60 \mathrm{mV}$. This is substantially more positive than the adult RMP $(-85 \mathrm{mV})$, and even higher than the neonatal one $(-60 \mathrm{mV}$ to $-70 \mathrm{mV})[202$, 203]. Moreover, the electrical immaturity of hPSC-CMs is displayed by strong depolarizing currents (such as $I_{\mathrm{f}}$ and $I_{\mathrm{CaT}}$ ), combined with low/absent $I_{\mathrm{K} 1}$ hyperpolarizing current (Table 1).

With regards to hPSC-CM metabolism, mitochondria are small, fewer in number, and localized in the perinuclear region rather than being intermyofibrillar or subsarcolemmal as in the adult heart [204]. Further, the rudimentary cristae and the low expression of CPT1 on the mitochondrial membrane lead to a reduced uptake of fatty acids [205, 206]. Therefore, the preferred metabolic substrates of hPSC-CMs are glucose and lactate, which as described earlier are processed by glycolysis and inhibit fatty acid $\beta$-oxidation [77, 
205-207]. The cell-cycle dynamics of hPSC-CMs are also indicative of immaturity, as the cells have a relatively high proliferative capacity [208] and low levels of polyploidy [209]. Finally, hPSC-CMs globally resemble fetal CMs from a transcriptional and epigenetic level, as confirmed by genome-wide assays, including RNA sequencing (RNAseq), and the analysis of transcription factor-binding (ChIPseq), chromatin accessibility (ATAC-seq), and 3D genome architecture (Hi-C) [28, 140, 210].

\section{Strategies for hPSC-CM Maturation}

Over the last decade, multiple approaches have been put forward to enhance hPSC-CM maturation, as discussed in a number of excellent reviews [26, 196, 211]. While the scope of this review is distinct, and thus we do not wish to present a complete overview of this extensive field, in this short section we summarize the state of the art and highlight current limitations.

Long-term culture of hPSC-CMs was the first and simplest approach to improve their maturation. Indeed, full physiological maturation of human cardiomyocytes occurs between 6 and 10 years of age [147]. This can be partially mimicked by culturing hPSC-CMs in vitro for up to one year [209, 210, 212, 213]. While this approach does not require specialized equipment, it is inefficient, expensive, and laborintensive. Moreover, even after 200 days of culture, the phenotype of hPSC-CMs is nowhere near complete maturation (Table 2). Considering that this method also suffers from large batch-to-batch variability and limited yield, it is unsuitable for scalable production [196, 211].

Physical stimulation either by mechanical or electrical means can speed up hPSC-CM maturation by promoting expression of contractile proteins and structural organization (Table 2) [214], similarly to what is observed during natural development $[66,70]$. This has been most successful in engineered heart tissues, where mechanical loading can be controlled more readily [198-200,215]. Tissue engineering aims to closely mimic the environment of developing cardiomyocytes by embedding them into a 3D matrix in the presence of other noncardiac cells. For instance, progressive increase in afterload leads to increased twitch force, highly organized sarcomeres, and increased expression of $\beta$-MHC [214, 216]. Electrical stimulation alone or in combination with mechanical stress also enhances E-C coupling in engineered heart tissues by promoting gap junction formation, sarcomere organization, and SERCA2a and RYR2 expression [217, 218]. However, long-term exposure to excessive physical stimulation can induce markers of pathological hypertrophy and fibrosis [214, 217]. When 3D-EHTs are further stimulated by electrical and/ or mechanical means, hPSC-CMs grow to develop adultlike features such as increased sarcomere length $(\sim 2.2 \mu \mathrm{m})$, higher mitochondrial density (up to $30 \%$ of the cell volume), presence of T-tubules, strong oxidative metabolism, and efficient E-C coupling (Table 2) [199, 200, 214, 215, 219]. Furthermore, despite substantial recent progress in automation and scalability [215, 220], generation of 3D-EHTs for highthroughput analyses and/or regeneration of large portions of the myocardium is still very challenging.

Multiple approaches have been identified that enhance cardiomyocyte maturation in 2D culture. For example, coculturing hPSC-CMs with endothelial cells enhances maturity, in part through upregulation of miRNAs miR-125b-5p, miR-199a-5p, miR-221, and miR-222 [221]. Cardiomyocytes respond to substrate cues such as nanotopology, and culturing them on surfaces containing sub-micrometer grooves enhances alignment of the contractile cytoskeleton [222]. This has allowed isolation of single myofibrils from hPSC-CMs derived from patients with familial cardiomyopathy [223]. Further maturation of conduction velocities and calcium handling occurs when the conductivity of the nanogrooved substrate is enhanced with graphene oxide [224].

Maturation can also be promoted via stimulation with growth factors and/or hormones such IGF [208, 225], glucocorticoids [34], and T3 [33, 34, 226]. While these individual treatments improve to some degree sarcomere organization, electrical coupling, and contractility, hPSC-CMs are still largely immature. Overexpression of let-7 family miRNAs, which are highly upregulated during long-term hPSC-CM maturation in vitro, also leads to a more mature phenotype, including stimulating fatty acid metabolism, increased cell size, sarcomere length, force of contraction, and respiratory capacity [227].

We emphasize that, however, with the possible exception of electrically paced engineered heart tissues, in all of these cases hPSC-CMs are still only comparable to neonatal cardiomyocytes. Overall, while these approaches are in principle easily scalable and may be effective to improve cardiac maturation, the lack of a truly mature phenotype still hinders application of hPSC-CMs for certain sensitive applications such as pharmacology and toxicology studies.

\section{Conclusion and Future Directions}

Late gestational and postnatal cardiac development is characterized by multiple complex pathways that gradually promote the transition of fetal cardiomyocytes into neonatal and finally adult stages. Unfortunately, we still have incomplete mechanistic knowledge of this process, particularly with regard to late gestational development. Thus, we expect that major advances in our ability to mature hPSC-CMs will rely on much more extensive studies of the basic biology underlying physiological cardiac maturation. Nevertheless, as summarized above, there are a large number of pathways 


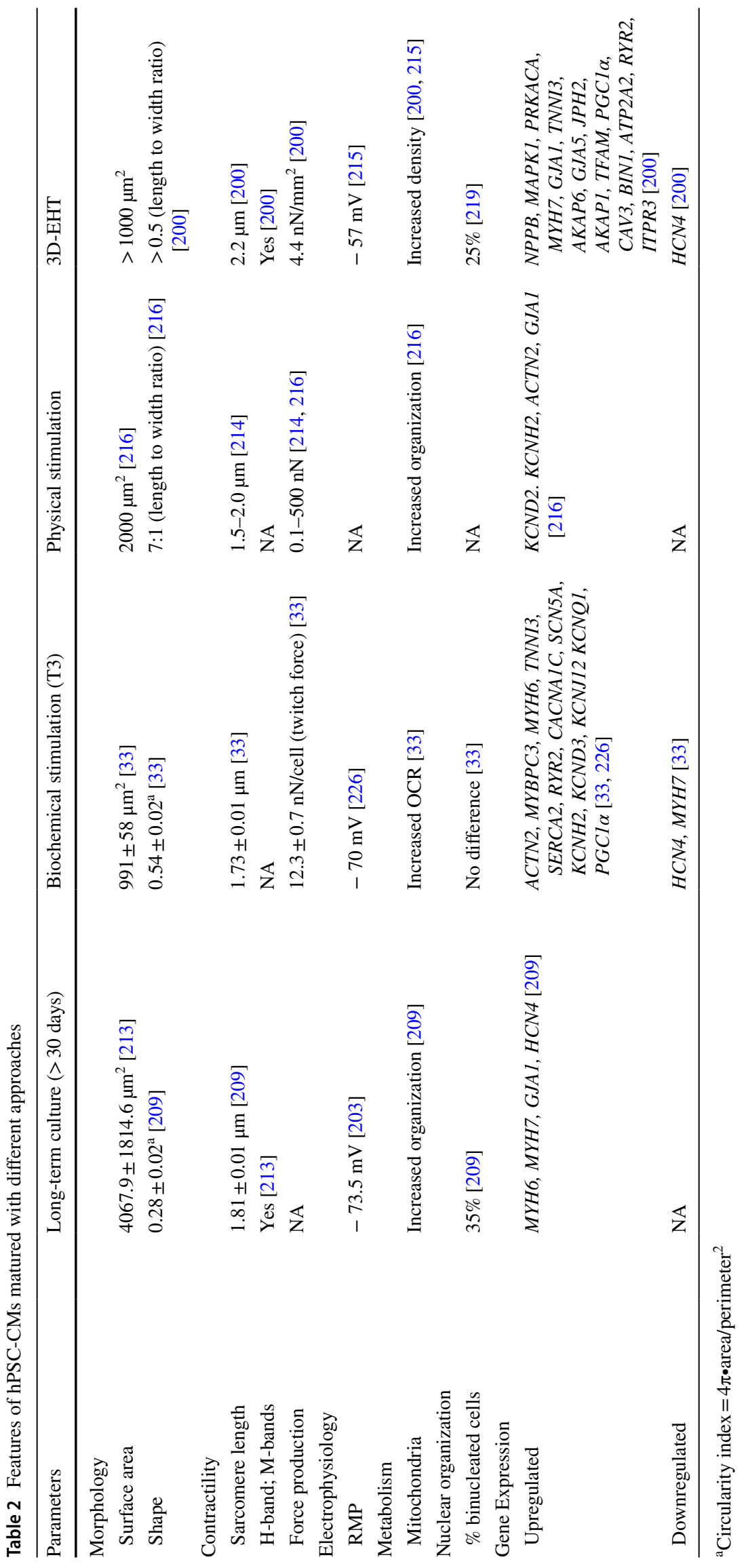


already known to control cardiac maturation, which have not yet been extensively tested in hPSC-CMs.

At least two important aspects must be considered while trying to achieve hPSC-CM maturation. First, the required level of maturation will heavily depend on the specific application. For instance, a truly adult phenotype would be highly advantageous for pharmacology, toxicology, and disease modeling studies. However, this might be unfavorable for regenerative medicine applications since adult cardiomyocytes do not survive transplantation into injured myocardium (while fetal and neonatal cells are more suitable [228]). Thus, cardiac maturation can represent a doubleedged sword that must be carefully balanced: we submit that a "one size fits all" approach is neither the most efficient nor appropriate way to tackle this problem.

The second key issue is one of scalability of mature hPSC-CMs production. As discussed, while many efficient approaches already exist to increase hPSC-CM maturation, most of these cannot currently be applied in a high-throughput fashion and/or for the generation of the large numbers of hiPSC-CMs required for regenerative medicine applications (which is estimated to require billions of cells per patient). Indeed, current "natural engineering" strategies to drive hPSC-CM maturation achieve results that are roughly proportional to the number of nature's cues that are being replicated in vitro. However, increasing the complexity of the culture conditions inversely correlates with scalability, costs, and reproducibility. Thus, we propose that methods that take not just inspiration from developmental lessons but are also able to implement them in novel ways will be highly valuable in the future. For instance, the ability to engineer cellular phenotypes with high efficiency by means of gene editing with CRISPR/Cas9 technology [229, 230] opens the opportunity to specifically alter transcriptional gene networks and/or specific metabolic pathways, ion channels, or sarcomeric proteins.

Overall, we hope that the knowledge gathered in this review may catalyze further explorations of the fundamental link between "natural" and "engineered" development to unlock the full potential of hPSC-CMs in the biomedical sciences.

Acknowledgements We thank all the current and past members of the Murry lab and of the UW Medicine Heart Regeneration Program for the insightful discussions.

Funding AB holds an EMBO Long-Term Fellowship (ALTF 4482017). CEM is supported by the National Institute of Health grants R01HL128362, R01H128368, R01HL141570, R01HL141868, U01HL100405, and a grant from the Fondation Leducq Transatlantic Network of Excellence.

\section{Compliance with Ethical Standards}

Conflict of interest CEM is a scientific founder and equity holder in Cytocardia.

Ethical Approval This article does not contain any studies with human participants or animals performed by any of the authors.

\section{References}

1. Thomson JA, Itskovitz-Eldor J, Shapiro SS, Waknitz MA, Swiergiel JJ, Marshall VS, Jones JM (1998) Embryonic stem cell lines derived from human blastocysts. Science 282:1145-1147

2. Takahashi K, Tanabe K, Ohnuki M, Narita M, Ichisaka T, Tomoda K, Yamanaka S (2007) Induction of pluripotent stem cells from adult human fibroblasts by defined factors. Cell 131:861-872

3. Yu J, Vodyanik MA, Smuga-Otto K, Antosiewicz-Bourget J, Frane JL, Tian S, Nie J, Jonsdottir GA, Ruotti V, Stewart R, Slukvin JA (2007) Induced pluripotent stem cell lines derived from human somatic cells. Science 318:1917-1920

4. Mummery CL, Zhang J, Ng ES, Elliott DA, Elefanty AG, Kamp TJ (2012) Differentiation of human embryonic stem cells and induced pluripotent stem cells to cardiomyocytes: a methods overview. Circ Res 111:344-358

5. Kattman SJ, Witty AD, Gagliardi M, Dubois NC, Niapour M, Hotta A, Ellis J, Keller G (2011) Stage-specific optimization of activin/nodal and BMP signaling promotes cardiac differentiation of mouse and human pluripotent stem cell lines. Cell Stem Cell 8:228-240

6. Yang L, Soonpaa MH, Adler ED, Roepke TK, Kattman SJ, Kennedy M, Henckaerts E, Bonham K, Abbott GW, Linden RM, Field LJ, Keller GM (2008) Human cardiovascular progenitor cells develop from a KDR+ embryonic-stem-cellderived population. Nature 453:524-528

7. Lian X, Hsiao C, Wilson G, Zhu K, Hazeltine LB, Azarin SM, Raval KK, Zhang J, Kamp TJ, Palecek SP (2012) Robust cardiomyocyte differentiation from human pluripotent stem cells via temporal modulation of canonical Wnt signaling. Proc Natl Acad Sci USA 109:E1848-1857

8. Zhang J, Wilson GF, Soerens AG, Koonce CH, Yu J, Palecek SP, Thomson JA, Kamp TJ (2009) Functional cardiomyocytes derived from human induced pluripotent stem cells. Circ Res 104:e30-41

9. Palpant NJ, Pabon L, Friedman CE, Roberts M, Hadland B, Zaunbrecher RJ, Bernstein I, Zheng Y, Murry CE (2017) Generating high-purity cardiac and endothelial derivatives from patterned mesoderm using human pluripotent stem cells. Nat Protoc 12:15-31

10. Protze SI, Liu J, Nussinovitch U, Ohana L, Backx PH, Gepstein L, Keller GM (2017) Sinoatrial node cardiomyocytes derived from human pluripotent cells function as a biological pacemaker. Nat Biotechnol 35:56-68

11. Paige SL, Thomas S, Stoick-Cooper CL, Wang H, Maves L, Sandstrom R, Pabon L, Reinecke H, Pratt G, Keller G, Moon RT, Stamatoyannopoulos J, Murry CE (2012) A temporal chromatin signature in human embryonic stem cells identifies regulators of cardiac development. Cell 151:221-232

12. Bertero A, Pawlowski M, Ortmann D, Snijders K, Yiangou L, Cardoso M, de Brito S, Brown WG Bernard, Cooper JD, Giacomelli E, Gambardella L, Hannan NR, Iyer D, Sampaziotis F, Serrano F, Zonneveld MC, Sinha S, Kotter M, Vallier L (2016) 
Optimized inducible shRNA and CRISPR/Cas9 platforms for in vitro studies of human development using hPSCs. Development 143:4405-4418

13. Doherty KR, Talbert DR, Trusk PB, Moran DM, Shell SA, Bacus $S$ (2015) Structural and functional screening in human induced-pluripotent stem cell-derived cardiomyocytes accurately identifies cardiotoxicity of multiple drug types. Toxicol Appl Pharmacol 285:51-60

14. Braam SR, Tertoolen L, van de Stolpe A, Meyer T, Passier R, Mummery CL (2010) Prediction of drug-induced cardiotoxicity using human embryonic stem cell-derived cardiomyocytes. Stem Cell Res 4:107-116

15. Ben Jehuda R, Barad L (2016) Patient specific induced pluripotent stem cell-derived cardiomyocytes for drug development and screening in catecholaminergic polymorphic ventricular tachycardia. J Atr Fibrillation 9:1423

16. Itzhaki I, Maizels L, Huber I, Zwi-Dantsis L, Caspi O, Winterstern A, Feldman O, Gepstein A, Arbel G, Hammerman H, Boulos M, Gepstein L (2011) Modelling the long QT syndrome with induced pluripotent stem cells. Nature 471:225-229

17. Laflamme MA, Chen KY, Naumova AV, Muskheli V, Fugate JA, Dupras SK, Reinecke H, Xu C, Hassanipour M, Police S, O'Sullivan C, Collins L, Chen Y, Minami E, Gill EA, Ueno S, Yuan C, Gold J, Murry CE (2007) Cardiomyocytes derived from human embryonic stem cells in pro-survival factors enhance function of infarcted rat hearts. Nat Biotechnol 25:1015-1024

18. Shiba Y, Fernandes S, Zhu WZ, Filice D, Muskheli V, Kim J, Palpant NJ, Gantz J, Moyes KW, Reinecke H, Van Biber B, Dardas T, Mignone JL, Izawa A, Hanna R, Viswanathan M, Gold JD, Kotlikoff MI, Sarvazyan N, Kay MW, Murry CE, Laflamme MA (2012) Human ES-cell-derived cardiomyocytes electrically couple and suppress arrhythmias in injured hearts. Nature 489:322-325

19. Chong JJ, Yang X, Don CW, Minami E, Liu YW, Weyers JJ, Mahoney WM, Van Biber B, Cook SM, Palpant NJ, Gantz JA, Fugate JA, Muskheli V, Gough GM, Vogel KW, Astley CA, Hotchkiss CE, Baldessari A, Pabon L, Reinecke H, Gill EA, Nelson V, Kiem HP, Laflamme MA, Murry CE (2014) Human embryonic-stem-cell-derived cardiomyocytes regenerate nonhuman primate hearts. Nature 510:273-277

20. Blinova K, Dang Q, Millard D, Smith G, Pierson J, Guo L, Brock M, Lu HR, Kraushaar U, Zeng H, Shi H, Zhang X, Sawada K, Osada T, Kanda Y, Sekino Y, Pang L, Feaster TK, Kettenhofen R, Stockbridge N, Strauss DG, Gintant G (2018) International multisite study of human-induced pluripotent stem cell-derived cardiomyocytes for drug proarrhythmic potential assessment. Cell Rep 24:3582-3592

21. Mordwinkin NM, Burridge PW, Wu JC (2013) A review of human pluripotent stem cell-derived cardiomyocytes for highthroughput drug discovery, cardiotoxicity screening, and publication standards. J Cardiovasc Transl Res 6:22-30

22. Liu YW, Chen B, Yang X, Fugate JA, Kalucki FA, FutakuchiTsuchida A, Couture L, Vogel KW, Astley CA, Baldessari A, Ogle J, Don CW, Steinberg ZL, Seslar SP, Tuck SA, Tsuchida H, Naumova AV, Dupras SK, Lyu MS, Lee J, Hailey DW, Reinecke H, Pabon L, Fryer BH, MacLellan WR, Thies RS, Murry CE (2018) Human embryonic stem cell-derived cardiomyocytes restore function in infarcted hearts of non-human primates. Nat Biotechnol 36:597-605

23. Bertero A, Murry CE (2018) Hallmarks of cardiac regeneration. Nat Rev Cardiol 15:579-580

24. Shiba Y, Gomibuchi T, Seto T, Wada Y, Ichimura H, Tanaka Y, Ogasawara T, Okada K, Shiba N, Sakamoto K, Ido D, Shiina T, Ohkura M, Nakai J, Uno N, Kazuki Y, Oshimura M, Minami I, Ikeda U (2016) Allogeneic transplantation of iPS cell-derived cardiomyocytes regenerates primate hearts. Nature 538:388-391

25. Tan SH, Ye L (2018) Maturation of pluripotent stem cell-derived cardiomyocytes: a critical step for drug development and cell therapy. J Cardiovasc Transl Res 11:375-392

26. Yang X, Pabon L, Murry CE (2014) Engineering adolescence: maturation of human pluripotent stem cell-derived cardiomyocytes. Circ Res 114:511-523

27. Snir M, Kehat I, Gepstein A, Coleman R, Itskovitz-Eldor J, Livne E, Gepstein L (2003) Assessment of the ultrastructural and proliferative properties of human embryonic stem cell-derived cardiomyocytes. Am J Physiol Heart Circ Physiol 285:H2355-2363

28. Synnergren J, Ameen C, Jansson A, Sartipy P (2012) Global transcriptional profiling reveals similarities and differences between human stem cell-derived cardiomyocyte clusters and heart tissue. Physiol Genomics 44:245-258

29. Murry CE, Keller G (2008) Differentiation of embryonic stem cells to clinically relevant populations: lessons from embryonic development. Cell 132:661-680

30. Yamaguchi TP, Takada S, Yoshikawa Y, Wu N, McMahon AP (1999) T (Brachyury) is a direct target of Wnt3a during paraxial mesoderm specification. Genes Dev 13:3185-3190

31. Li M, Iismaa SE, Naqvi N, Nicks A, Husain A, Graham RM (2014) Thyroid hormone action in postnatal heart development. Stem Cell Res 13:582-591

32. Liggins GC (1994) The role of cortisol in preparing the fetus for birth. Reprod Fertil Dev 6:141-150

33. Yang X, Rodriguez M, Pabon L, Fischer KA, Reinecke H, Regnier M, Sniadecki NJ, Ruohola-Baker H, Murry CE (2014) Tri-iodo-l-thyronine promotes the maturation of human cardiomyocytes-derived from induced pluripotent stem cells. J Mol Cell Cardiol 72:296-304

34. Parikh SS, Blackwell DJ, Gomez-Hurtado N, Frisk M, Wang L, Kim K, Dahl CP, Fiane A, Tonnessen T, Kryshtal DO, Louch WE, Knollmann BC (2017) Thyroid and glucocorticoid hormones promote functional T-tubule development in humaninduced pluripotent stem cell-derived cardiomyocytes. Circ Res 121:1323-1330

35. Uosaki H, Taguchi YH (2016) Comparative gene expression analysis of mouse and human cardiac maturation. Genomics Proteomics Bioinform 14:207-215

36. Garbern JC, Mummery CL, Lee RT (2013) Model systems for cardiovascular regenerative biology. Cold Spring Harb Perspect Med 3:a014019

37. Sylva M, van den Hoff MJ, Moorman AF (2014) Development of the human heart. Am J Med Genet A 164A:1347-1371

38. Rossant J, Tam PP (2009) Blastocyst lineage formation, early embryonic asymmetries and axis patterning in the mouse. Development 136:701-713

39. Rana MS, Christoffels VM, Moorman AF (2013) A molecular and genetic outline of cardiac morphogenesis. Acta Physiol (Oxf) 207:588-615

40. Meilhac SM, Esner M, Kelly RG, Nicolas JF, Buckingham ME (2004) The clonal origin of myocardial cells in different regions of the embryonic mouse heart. Dev Cell 6:685-698

41. Gong H, Lyu X, Wang Q, Hu M, Zhang X (2017) Endothelial to mesenchymal transition in the cardiovascular system. Life Sci 184:95-102

42. Lincoln J, Garg V (2014) Etiology of valvular heart diseasegenetic and developmental origins. Circ J 78:1801-1807

43. Rochais F, Mesbah K, Kelly RG (2009) Signaling pathways controlling second heart field development. Circ Res 104:933-942

44. Zaffran S, Kelly RG, Meilhac SM, Buckingham ME, Brown NA (2004) Right ventricular myocardium derives from the anterior heart field. Circ Res 95:261-268 
45. Lavine KJ, Ornitz DM (2008) Fibroblast growth factors and Hedgehogs: at the heart of the epicardial signaling center. Trends Genet 24:33-40

46. Cai CL, Martin JC, Sun Y, Cui L, Wang L, Ouyang K, Yang L, Bu L, Liang X, Zhang X, Stallcup WB, Denton CP, McCulloch A, Chen J, Evans SM (2008) A myocardial lineage derives from Tbx 18 epicardial cells. Nature 454:104-108

47. Stevens SM, von Gise A, VanDusen N, Zhou B, Pu WT (2016) Epicardium is required for cardiac seeding by yolk sac macrophages, precursors of resident macrophages of the adult heart. Dev Biol 413:153-159

48. Bressan M, Liu G, Mikawa T (2013) Early mesodermal cues assign avian cardiac pacemaker fate potential in a tertiary heart field. Science 340:744-748

49. Liang X, Evans SM, Sun Y (2017) Development of the cardiac pacemaker. Cell Mol Life Sci 74:1247-1259

50. Kelder TP, Vicente-Steijn R, Harryvan TJ, Kosmidis G, Gittenberger-de Groot AC, Poelmann RE, Schalij MJ, DeRuiter MC, Jongbloed MR (2015) The sinus venosus myocardium contributes to the atrioventricular canal: potential role during atrioventricular node development? J Cell Mol Med 19:1375-1389

51. Christoffels VM, Smits GJ, Kispert A, Moorman AF (2010) Development of the pacemaker tissues of the heart. Circ Res 106:240-254

52. Paff GH, Boucek RJ, Harrell TC (1968) Observations on the development of the electrocardiogram. Anat Rec 160:575-582

53. Forouhar AS, Liebling M, Hickerson A, Nasiraei-Moghaddam A, Tsai HJ, Hove JR, Fraser SE, Dickinson ME, Gharib M (2006) The embryonic vertebrate heart tube is a dynamic suction pump. Science 312:751-753

54. Giovannone S, Remo BF, Fishman GI (2012) Channeling diversity: gap junction expression in the heart. Heart Rhythm 9:1159-1162

55. Moorman AF, Christoffels VM (2003) Cardiac chamber formation: development, genes, and evolution. Physiol Rev 83:1223-1267

56. Mohan RA, Mommersteeg MTM, Dominguez JN, Choquet C, Wakker V, de Gier-de Vries C, Boink GJJ, Boukens BJ, Miquerol L, Verkerk AO, Christoffels VM (2018) Embryonic Tbx3(+) cardiomyocytes form the mature cardiac conduction system by progressive fate restriction. Development 145:dev167361

57. Mohan RA, Boukens BJ, Christoffels VM (2018) Developmental origin of the cardiac conduction system: insight from lineage tracing. Pediatr Cardiol 39:1107-1114

58. Plein A, Fantin A, Ruhrberg C (2015) Neural crest cells in cardiovascular development. Curr Top Dev Biol 111:183-200

59. Manner J (2009) The anatomy of cardiac looping: a step towards the understanding of the morphogenesis of several forms of congenital cardiac malformations. Clin Anat 22:21-35

60. Sedmera D, Pexieder T, Vuillemin M, Thompson RP, Anderson RH (2000) Developmental patterning of the myocardium. Anat Rec 258:319-337

61. Del Monte-Nieto G, Ramialison M, Adam AAS, Wu B, Aharonov A, D’Uva G, Bourke LM, Pitulescu ME, Chen H, de la Pompa JL, Shou W, Adams RH, Harten SK, Tzahor E, Zhou B, Harvey RP (2018) Control of cardiac jelly dynamics by NOTCH1 and NRG1 defines the building plan for trabeculation. Nature 557:439-445

62. Zhang W, Chen H, Qu X, Chang CP, Shou W (2013) Molecular mechanism of ventricular trabeculation/compaction and the pathogenesis of the left ventricular noncompaction cardiomyopathy (LVNC). Am J Med Genet C 163C:144-156

63. Christoffels VM, Habets PE, Franco D, Campione M, de Jong F, Lamers WH, Bao ZZ, Palmer S, Biben C, Harvey RP, Moorman AF (2000) Chamber formation and morphogenesis in the developing mammalian heart. Dev Biol 223:266-278
64. Lunkenheimer PP, Redmann K, Kling N, Jiang X, Rothaus K, Cryer CW, Wubbeling F, Niederer P, Heitz PU, Ho SY, Anderson RH (2006) Three-dimensional architecture of the left ventricular myocardium. Anat Rec A 288:565-578

65. Sosnovik DE, Geva T (2018) Imaging the Microstructure of the Human Fetal Heart. Circ Cardiovasc Imaging 11:e008298

66. McCain ML, Parker KK (2011) Mechanotransduction: the role of mechanical stress, myocyte shape, and cytoskeletal architecture on cardiac function. Pflugers Arch 462:89-104

67. Lindsey SE, Butcher JT, Yalcin HC (2014) Mechanical regulation of cardiac development. Front Physiol 5:318

68. Granados-Riveron JT, Brook JD (2012) The impact of mechanical forces in heart morphogenesis. Circ Cardiovasc Genet 5:132-142

69. Struijk PC, Mathews VJ, Loupas T, Stewart PA, Clark EB, Steegers EA, Wladimiroff JW (2008) Blood pressure estimation in the human fetal descending aorta. Ultrasound Obstet Gynecol 32:673-681

70. Damon BJ, Remond MC, Bigelow MR, Trusk TC, Xie W, Perucchio R, Sedmera D, Denslow S, Thompson RP (2009) Patterns of muscular strain in the embryonic heart wall. Dev Dyn 238:1535-1546

71. Hove JR, Koster RW, Forouhar AS, Acevedo-Bolton G, Fraser SE, Gharib M (2003) Intracardiac fluid forces are an essential epigenetic factor for embryonic cardiogenesis. Nature 421:172-177

72. Sedmera D, Hu N, Weiss KM, Keller BB, Denslow S, Thompson RP (2002) Cellular changes in experimental left heart hypoplasia. Anat Rec 267:137-145

73. MacGrogan D, Munch J, de la Pompa JL (2018) Notch and interacting signalling pathways in cardiac development, disease, and regeneration. Nat Rev Cardiol 15:685-704

74. Lai D, Liu X, Forrai A, Wolstein O, Michalicek J, Ahmed I, Garratt AN, Birchmeier C, Zhou M, Hartley L, Robb L, Feneley MP, Fatkin D, Harvey RP (2010) Neuregulin 1 sustains the gene regulatory network in both trabecular and nontrabecular myocardium. Circ Res 107:715-727

75. Chen H, Shi S, Acosta L, Li W, Lu J, Bao S, Chen Z, Yang Z, Schneider MD, Chien KR, Conway SJ, Yoder MC, Haneline LS, Franco D, Shou W (2004) BMP10 is essential for maintaining cardiac growth during murine cardiogenesis. Development 131:2219-2231

76. Kochilas LK, Li J, Jin F, Buck CA, Epstein JA (1999) p57Kip2 expression is enhanced during mid-cardiac murine development and is restricted to trabecular myocardium. Pediatr Res 45:635-642

77. Lunt SY, Vander Heiden MG (2011) Aerobic glycolysis: meeting the metabolic requirements of cell proliferation. Annu Rev Cell Dev Biol 27:441-464

78. Veille JC, Hanson R, Sivakoff M, Hoen H, Ben-Ami M (1993) Fetal cardiac size in normal, intrauterine growth retarded, and diabetic pregnancies. Am J Perinatol 10:275-279

79. Lopaschuk GD, Jaswal JS (2010) Energy metabolic phenotype of the cardiomyocyte during development, differentiation, and postnatal maturation. J Cardiovasc Pharmacol 56:130-140

80. Makinde AO, Kantor PF, Lopaschuk GD (1998) Maturation of fatty acid and carbohydrate metabolism in the newborn heart. Mol Cell Biochem 188:49-56

81. Wiberg-Itzel E, Lipponer C, Norman M, Herbst A, Prebensen D, Hansson A, Bryngelsson AL, Christoffersson M, Sennstrom M, Wennerholm UB, Nordstrom L (2008) Determination of $\mathrm{pH}$ or lactate in fetal scalp blood in management of intrapartum fetal distress: randomised controlled multicentre trial. BMJ 336:1284-1287

82. Iruretagoyena JI, Davis W, Bird C, Olsen J, Radue R, Teo Broman A, Kendziorski C, Splinter BonDurant S, Golos T, Bird I, 
Shah D (2014) Metabolic gene profile in early human fetal heart development. Mol Hum Reprod 20:690-700

83. Patterson AJ, Zhang L (2010) Hypoxia and fetal heart development. Curr Mol Med 10:653-666

84. Krishnan J, Ahuja P, Bodenmann S, Knapik D, Perriard E, Krek W, Perriard JC (2008) Essential role of developmentally activated hypoxia-inducible factor 1alpha for cardiac morphogenesis and function. Circ Res 103:1139-1146

85. Menendez-Montes I, Escobar B, Palacios B, Gomez MJ, Izquierdo-Garcia JL, Flores L, Jimenez-Borreguero LJ, Aragones J, Ruiz-Cabello J, Torres M, Martin-Puig S (2016) Myocardial VHL-HIF signaling controls an embryonic metabolic switch essential for cardiac maturation. Dev Cell 39:724-739

86. Hillman NH, Kallapur SG, Jobe AH (2012) Physiology of transition from intrauterine to extrauterine life. Clin Perinatol 39:769-783

87. Jett PL, Samuels MH, McDaniel PA, Benda GI, Lafranchi SH, Reynolds JW, Hanna CE (1997) Variability of plasma cortisol levels in extremely low birth weight infants. J Clin Endocrinol Metab 82:2921-2925

88. Asakura H (2004) Fetal and neonatal thermoregulation. J Nippon Med Sch 71:360-370

89. Kim MY, Eiby YA, Lumbers ER, Wright LL, Gibson KJ, Barnett AC, Lingwood BE (2014) Effects of glucocorticoid exposure on growth and structural maturation of the heart of the preterm piglet. PLoS ONE 9:e93407

90. Rog-Zielinska EA, Craig MA, Manning JR, Richardson RV, Gowans GJ, Dunbar DR, Gharbi K, Kenyon CJ, Holmes MC, Hardie DG, Smith GL, Chapman KE (2015) Glucocorticoids promote structural and functional maturation of foetal cardiomyocytes: a role for PGC-1alpha. Cell Death Differ 22:1106-1116

91. Liang H, Ward WF (2006) PGC-1alpha: a key regulator of energy metabolism. Adv Physiol Educ 30:145-151

92. Fisher DA (2008) Thyroid system immaturities in very low birth weight premature infants. Semin Perinatol 32:387-397

93. Davis PJ, Goglia F, Leonard JL (2016) Nongenomic actions of thyroid hormone. Nat Rev Endocrinol 12:111-121

94. Davis PJ, Davis FB (2002) Nongenomic actions of thyroid hormone on the heart. Thyroid 12:459-466

95. Ratajczak P, Oliviero P, Marotte F, Kolar F, Ostadal B, Samuel JL (1985) (2005) Expression and localization of caveolins during postnatal development in rat heart: implication of thyroid hormone. J Appl Physiol 99:244-251

96. Hirose K, Payumo AY, Cutie S, Hoang A, Zhang H, Guyot R, Lunn D, Bigley RB, Yu H, Wang J, Smith M, Gillett E, Muroy SE, Schmid T, Wilson E, Field KA, Reeder DM, Maden M, Yartsev MM, Wolfgang MJ, Grutzner F, Scanlan TS, Szweda LI, Buffenstein R, Hu G, Flamant F, Olgin JE, Huang GN (2019) Evidence for hormonal control of heart regenerative capacity during endothermy acquisition. Science 364:184-188

97. Castello A, Rodriguez-Manzaneque JC, Camps M, Perez-Castillo A, Testar X, Palacin M, Santos A, Zorzano A (1994) Perinatal hypothyroidism impairs the normal transition of GLUT4 and GLUT1 glucose transporters from fetal to neonatal levels in heart and brown adipose tissue. Evidence for tissue-specific regulation of GLUT4 expression by thyroid hormone. J Biol Chem 269:5905-5912

98. Jones CT, Rolph TP (1985) Metabolism during fetal life: a functional assessment of metabolic development. Physiol Rev 65:357-430

99. MacLennan DH, Kranias EG (2003) Phospholamban: a crucial regulator of cardiac contractility. Nat Rev Mol Cell Biol 4:566-577

100. Alzaree FA, AbuShady MM, Atti MA, Fathy GA, Galal EM, Ali A, Elias TR (2019) Effect of early breast milk nutrition on serum insulin-like growth factor-1 in preterm infants. Open Access Maced J Med Sci 7:77-81

101. Hellstrom A, Ley D, Hansen-Pupp I, Hallberg B, Lofqvist C, van Marter L, van Weissenbruch M, Ramenghi LA, Beardsall K, Dunger D, Hard AL, Smith LE (2016) Insulin-like growth factor 1 has multisystem effects on foetal and preterm infant development. Acta Paediatr 105:576-586

102. Clemmons DR (2012) Metabolic actions of insulin-like growth factor-I in normal physiology and diabetes. Endocrinol Metab Clin North Am 41:425-443, vii-viii

103. Fowden AL (1992) The role of insulin in fetal growth. Early Hum Dev 29:177-181

104. Luiken JJ, Koonen DP, Willems J, Zorzano A, Becker C, Fischer Y, Tandon NN, Van Der Vusse GJ, Bonen A, Glatz JF (2002) Insulin stimulates long-chain fatty acid utilization by rat cardiac myocytes through cellular redistribution of FAT/CD36. Diabetes 51:3113-3119

105. Colao A, Marzullo P, Di Somma C, Lombardi G (2001) Growth hormone and the heart. Clin Endocrinol (Oxf) 54:137-154

106. Heron-Milhavet L, Haluzik M, Yakar S, Gavrilova O, Pack S, Jou WC, Ibrahimi A, Kim H, Hunt D, Yau D, Asghar Z, Joseph J, Wheeler MB, Abumrad NA, LeRoith D (2004) Muscle-specific overexpression of CD36 reverses the insulin resistance and diabetes of MKR mice. Endocrinology 145:4667-4676

107. Ito H, Hiroe M, Hirata Y, Tsujino M, Adachi S, Shichiri M, Koike A, Nogami A, Marumo F (1993) Insulin-like growth factor-I induces hypertrophy with enhanced expression of muscle specific genes in cultured rat cardiomyocytes. Circulation 87:1715-1721

108. Hashima JN, Rogers V, Langley SM, Ashraf M, Sahn DJ, Ohtonen P, Davis LE, Hohimer AR, Rasanen J (2015) Fetal ventricular interactions and wall mechanics during ductus arteriosus occlusion in a sheep model. Ultrasound Med Biol 41:1020-1028

109. Heymann MA, Rudolph AM (1975) Control of the ductus arteriosus. Physiol Rev 55:62-78

110. Pinto AR, Ilinykh A, Ivey MJ, Kuwabara JT, D'Antoni ML, Debuque R, Chandran A, Wang L, Arora K, Rosenthal NA, Tallquist MD (2016) Revisiting cardiac cellular composition. Circ Res 118:400-409

111. Ieda M, Tsuchihashi T, Ivey KN, Ross RS, Hong TT, Shaw RM, Srivastava D (2009) Cardiac fibroblasts regulate myocardial proliferation through beta1 integrin signaling. Dev Cell 16:233-244

112. De Smedt MC, Visser GH, Meijboom EJ (1987) Fetal cardiac output estimated by Doppler echocardiography during mid- and late gestation. Am J Cardiol 60:338-342

113. Theodore RF, Broadbent J, Nagin D, Ambler A, Hogan S, Ramrakha S, Cutfield W, Williams MJ, Harrington H, Moffitt TE, Caspi A, Milne B, Poulton R (2015) Childhood to early-midlife systolic blood pressure trajectories: early-life predictors, effect modifiers, and adult cardiovascular outcomes. Hypertension 66:1108-1115

114. Hamill N, Yeo L, Romero R, Hassan SS, Myers SA, Mittal P, Kusanovic JP, Balasubramaniam M, Chaiworapongsa T, Vaisbuch E, Espinoza J, Gotsch F, Goncalves LF, Lee W (2011) Fetal cardiac ventricular volume, cardiac output, and ejection fraction determined with 4-dimensional ultrasound using spatiotemporal image correlation and virtual organ computer-aided analysis. Am J Obstet Gynecol 205(76):e71-e10

115. Nagasawa $H$ (2014) Evaluation of left ventricular volumes in the early neonatal period using three-dimensional echocardiography. Cardiol Young 24:685-693

116. Qu Y, Boutjdir M (2001) Gene expression of SERCA2a and Land T-type Ca channels during human heart development. Pediatr Res 50:569-574

117. Stieber J, Herrmann S, Feil S, Loster J, Feil R, Biel M, Hofmann F, Ludwig A (2003) The hyperpolarization-activated 
channel HCN4 is required for the generation of pacemaker action potentials in the embryonic heart. Proc Natl Acad Sci USA 100:15235-15240

118. Milano A, Vermeer AM, Lodder EM, Barc J, Verkerk AO, Postma AV, van der Bilt IA, Baars MJ, van Haelst PL, Caliskan K, Hoedemaekers YM, Le Scouarnec S, Redon R, Pinto YM, Christiaans I, Wilde AA, Bezzina CR (2014) HCN4 mutations in multiple families with bradycardia and left ventricular noncompaction cardiomyopathy. J Am Coll Cardiol 64:745-756

119. Yaniv Y, Lakatta EG (2013) Pacemaker gene mutations, bradycardia, arrhythmias and the coupled clock theory. J Cardiovasc Electrophysiol 24:E28-29

120. Bruneau BG (2008) The developmental genetics of congenital heart disease. Nature 451:943-948

121. Sizarov A, Devalla HD, Anderson RH, Passier R, Christoffels VM, Moorman AF (2011) Molecular analysis of patterning of conduction tissues in the developing human heart. Circ Arrhythm Electrophysiol 4:532-542

122. Zorn-Pauly K, Schaffer P, Pelzmann B, Bernhart E, Lang P, Zink M, Machler H, Rigler B, Koidl B (2003) A hyperpolarization activated inward current (If) is present in infant ventricular myocytes. Basic Res Cardiol 98:362-366

123. Song GL, Tang M, Liu CJ, Luo HY, Liang HM, Hu XW, Xi JY, Gao LL, Fleischmann B, Hescheler J (2002) Developmental changes in functional expression and beta-adrenergic regulation of I(f) in the heart of mouse embryo. Cell Res 12:385-394

124. Javorka K, Lehotska Z, Kozar M, Uhrikova Z, Kolarovszki B, Javorka M, Zibolen M (2017) Heart rate variability in newborns. Physiol Res 66:S203-S214

125. Verkerk AO, Wilders R, van Borren MM, Peters RJ, Broekhuis E, Lam K, Coronel R, de Bakker JM, Tan HL (2007) Pacemaker current (I(f)) in the human sinoatrial node. Eur Heart J 28:2472-2478

126. Qu Y, Ghatpande A, El-Sherif N, Boutjdir M (2000) Gene expression of $\mathrm{Na}+/ \mathrm{Ca} 2+$ exchanger during development in human heart. Cardiovasc Res 45:866-873

127. Harrell MD, Harbi S, Hoffman JF, Zavadil J, Coetzee WA (2007) Large-scale analysis of ion channel gene expression in the mouse heart during perinatal development. Physiol Genomics 28:273-283

128. Rosemblit N, Moschella MC, Ondriasova E, Gutstein DE, Ondrias K, Marks AR (1999) Intracellular calcium release channel expression during embryogenesis. Dev Biol 206:163-177

129. Kapoor N, Tran A, Kang J, Zhang R, Philipson KD, Goldhaber JI (2015) Regulation of calcium clock-mediated pacemaking by inositol-1,4,5-trisphosphate receptors in mouse sinoatrial nodal cells. J Physiol 593:2649-2663

130. Kato Y, Masumiya H, Agata N, Tanaka H, Shigenobu K (1996) Developmental changes in action potential and membrane currents in fetal, neonatal and adult guinea-pig ventricular myocytes. J Mol Cell Cardiol 28:1515-1522

131. Davies MP, An RH, Doevendans P, Kubalak S, Chien KR, Kass RS (1996) Developmental changes in ionic channel activity in the embryonic murine heart. Circ Res 78:15-25

132. Ye W, Wang J, Song Y, Yu D, Sun C, Liu C, Chen F, Zhang Y, Wang F, Harvey RP, Schrader L, Martin JF, Chen Y (2015) A common Shox2-Nkx2-5 antagonistic mechanism primes the pacemaker cell fate in the pulmonary vein myocardium and sinoatrial node. Development 142:2521-2532

133. Kuwahara K, Saito Y, Takano M, Arai Y, Yasuno S, Nakagawa Y, Takahashi N, Adachi Y, Takemura G, Horie M, Miyamoto Y, Morisaki T, Kuratomi S, Noma A, Fujiwara H, Yoshimasa Y, Kinoshita H, Kawakami R, Kishimoto I, Nakanishi M, Usami S, Saito Y, Harada M, Nakao K (2003) NRSF regulates the fetal cardiac gene program and maintains normal cardiac structure and function. EMBO J 22:6310-6321
134. Niwa N, Yasui K, Opthof T, Takemura H, Shimizu A, Horiba M, Lee JK, Honjo H, Kamiya K, Kodama I (2004) Cav3.2 subunit underlies the functional $\mathrm{T}$-type $\mathrm{Ca} 2+$ channel in murine hearts during the embryonic period. Am J Physiol Heart Circ Physiol 286:H2257-2263

135. Nuss HB, Marban E (1994) Electrophysiological properties of neonatal mouse cardiac myocytes in primary culture. J Physiol 479(Pt 2):265-279

136. Hartman ME, Liu Y, Zhu WZ, Chien WM, Weldy CS, Fishman GI, Laflamme MA, Chin MT (2014) Myocardial deletion of transcription factor $\mathrm{CHF} 1 / \mathrm{Hey} 2$ results in altered myocyte action potential and mild conduction system expansion but does not alter conduction system function or promote spontaneous arrhythmias. FASEB J 28:3007-3015

137. Khandekar A, Springer S, Wang W, Hicks S, Weinheimer C, Diaz-Trelles R, Nerbonne JM, Rentschler S (2016) Notch-mediated epigenetic regulation of voltage-gated potassium currents. Circ Res 119:1324-1338

138. Siedner S, Kruger M, Schroeter M, Metzler D, Roell W, Fleischmann BK, Hescheler J, Pfitzer G, Stehle R (2003) Developmental changes in contractility and sarcomeric proteins from the early embryonic to the adult stage in the mouse heart. J Physiol 548:493-505

139. Lahmers S, Wu Y, Call DR, Labeit S, Granzier H (2004) Developmental control of titin isoform expression and passive stiffness in fetal and neonatal myocardium. Circ Res 94:505-513

140. Bertero A, Fields PA, Ramani V, Bonora G, Yardimci GG, Reinecke H, Pabon L, Noble WS, Shendure J, Murry CE (2019) Dynamics of genome reorganization during human cardiogenesis reveal an RBM20-dependent splicing factory. Nat Commun 10:1538

141. Palmer BM (2005) Thick filament proteins and performance in human heart failure. Heart Fail Rev 10:187-197

142. Mahdavi V, Lompre AM, Chambers AP, Nadal-Ginard B (1984) Cardiac myosin heavy chain isozymic transitions during development and under pathological conditions are regulated at the level of mRNA availability. Eur Heart J 5(Suppl F):181-191

143. Hasenfuss G, Mulieri LA, Blanchard EM, Holubarsch C, Leavitt BJ, Ittleman F, Alpert NR (1991) Energetics of isometric force development in control and volume-overload human myocardium. Comparison with animal species. Circ Res 68:836-846

144. Gorza L, Ausoni S, Merciai N, Hastings KE, Schiaffino S (1993) Regional differences in troponin I isoform switching during rat heart development. Dev Biol 156:253-264

145. Westfall MV, Rust EM, Metzger JM (1997) Slow skeletal troponin I gene transfer, expression, and myofilament incorporation enhances adult cardiac myocyte contractile function. Proc Natl Acad Sci USA 94:5444-5449

146. Noorman M, van der Heyden MA, van Veen TA, Cox MG, Hauer RN, de Bakker JM, van Rijen HV (2009) Cardiac cell-cell junctions in health and disease: Electrical versus mechanical coupling. J Mol Cell Cardiol 47:23-31

147. Peters NS, Severs NJ, Rothery SM, Lincoln C, Yacoub MH, Green CR (1994) Spatiotemporal relation between gap junctions and fascia adherens junctions during postnatal development of human ventricular myocardium. Circulation 90:713-725

148. Wang Q, Lin JL, Chan SY, Lin JJ (2013) The Xin repeat-containing protein, mXinbeta, initiates the maturation of the intercalated discs during postnatal heart development. Dev Biol 374:264-280

149. Hirschy A, Schatzmann F, Ehler E, Perriard JC (2006) Establishment of cardiac cytoarchitecture in the developing mouse heart. Dev Biol 289:430-441

150. Galbiati F, Engelman JA, Volonte D, Zhang XL, Minetti C, Li M, Hou H Jr, Kneitz B, Edelmann W, Lisanti MP (2001) Caveolin-3 null mice show a loss of caveolae, changes in the microdomain 
distribution of the dystrophin-glycoprotein complex, and t-tubule abnormalities. J Biol Chem 276:21425-21433

151. Fu Y, Hong T (2016) BIN1 regulates dynamic t-tubule membrane. Biochim Biophys Acta 1863:1839-1847

152. van Oort RJ, Garbino A, Wang W, Dixit SS, Landstrom AP, Gaur N, De Almeida AC, Skapura DG, Rudy Y, Burns AR, Ackerman MJ, Wehrens XH (2011) Disrupted junctional membrane complexes and hyperactive ryanodine receptors after acute junctophilin knockdown in mice. Circulation 123:979-988

153. Chung JH, Biesiadecki BJ, Ziolo MT, Davis JP, Janssen PM (2016) Myofilament calcium sensitivity: role in regulation of in vivo cardiac contraction and relaxation. Front Physiol 7:562

154. Wiegerinck RF, Cojoc A, Zeidenweber CM, Ding G, Shen M, Joyner RW, Fernandez JD, Kanter KR, Kirshbom PM, Kogon BE, Wagner MB (2009) Force frequency relationship of the human ventricle increases during early postnatal development. Pediatr Res 65:414-419

155. Holubarsch C, Ludemann J, Wiessner S, Ruf T, Schulte-Baukloh H, Schmidt-Schweda S, Pieske B, Posival H, Just H (1998) Shortening versus isometric contractions in isolated human failing and non-failing left ventricular myocardium: dependency of external work and force on muscle length, heart rate and inotropic stimulation. Cardiovasc Res 37:46-57

156. Wang Z, Ying Z, Bosy-Westphal A, Zhang J, Schautz B, Later W, Heymsfield SB, Muller MJ (2010) Specific metabolic rates of major organs and tissues across adulthood: evaluation by mechanistic model of resting energy expenditure. Am J Clin Nutr 92:1369-1377

157. Stepanov V, Mateo P, Gillet B, Beloeil JC, Lechene P, Hoerter JA (1997) Kinetics of creatine kinase in an experimental model of low phosphocreatine and ATP in the normoxic heart. Am J Physiol 273:C1397-1408

158. Lopaschuk GD, Ussher JR, Folmes CD, Jaswal JS, Stanley WC (2010) Myocardial fatty acid metabolism in health and disease. Physiol Rev 90:207-258

159. Neely JR, Morgan HE (1974) Relationship between carbohydrate and lipid metabolism and the energy balance of heart muscle. Annu Rev Physiol 36:413-459

160. Girard J, Ferre P, Pegorier JP, Duee PH (1992) Adaptations of glucose and fatty acid metabolism during perinatal period and suckling-weaning transition. Physiol Rev 72:507-562

161. Ballard O, Morrow AL (2013) Human milk composition: nutrients and bioactive factors. Pediatr Clin N Am 60:49-74

162. Werner JC, Sicard RE, Schuler HG (1989) Palmitate oxidation by isolated working fetal and newborn pig hearts. Am J Physiol 256:E315-321

163. An D, Pulinilkunnil T, Qi D, Ghosh S, Abrahani A, Rodrigues B (2005) The metabolic "switch" AMPK regulates cardiac heparin-releasable lipoprotein lipase. Am J Physiol Endocrinol Metab 288:E246-253

164. Makinde AO, Gamble J, Lopaschuk GD (1997) Upregulation of 5'-AMP-activated protein kinase is responsible for the increase in myocardial fatty acid oxidation rates following birth in the newborn rabbit. Circ Res 80:482-489

165. Lopaschuk GD, Witters LA, Itoi T, Barr R, Barr A (1994) Acetyl-CoA carboxylase involvement in the rapid maturation of fatty acid oxidation in the newborn rabbit heart. J Biol Chem 269:25871-25878

166. Piquereau J, Novotova M, Fortin D, Garnier A, Ventura-Clapier R, Veksler V, Joubert F (2010) Postnatal development of mouse heart: formation of energetic microdomains. J Physiol 588:2443-2454

167. Youle RJ, van der Bliek AM (2012) Mitochondrial fission, fusion, and stress. Science 337:1062-1065

168. Martin OJ, Lai L, Soundarapandian MM, Leone TC, Zorzano A, Keller MP, Attie AD, Muoio DM, Kelly DP (2014) A role for peroxisome proliferator-activated receptor gamma coactivator- 1 in the control of mitochondrial dynamics during postnatal cardiac growth. Circ Res 114:626-636

169. Scarpulla RC, Vega RB, Kelly DP (2012) Transcriptional integration of mitochondrial biogenesis. Trends Endocrinol Metab 23:459-466

170. Papanicolaou KN, Kikuchi R, Ngoh GA, Coughlan KA, Dominguez I, Stanley WC, Walsh K (2012) Mitofusins 1 and 2 are essential for postnatal metabolic remodeling in heart. Circ Res 111:1012-1026

171. Wilding JR, Joubert F, de Araujo C, Fortin D, Novotova M, Veksler V, Ventura-Clapier R (2006) Altered energy transfer from mitochondria to sarcoplasmic reticulum after cytoarchitectural perturbations in mice hearts. J Physiol 575:191-200

172. Soonpaa MH, Kim KK, Pajak L, Franklin M, Field LJ (1996) Cardiomyocyte DNA synthesis and binucleation during murine development. Am J Physiol 271:H2183-2189

173. Adler CP, Friedburg H (1986) Myocardial DNA content, ploidy level and cell number in geriatric hearts: post-mortem examinations of human myocardium in old age. J Mol Cell Cardiol 18:39-53

174. Bergmann O, Bhardwaj RD, Bernard S, Zdunek S, BarnabeHeider F, Walsh S, Zupicich J, Alkass K, Buchholz BA, Druid H, Jovinge S, Frisen J (2009) Evidence for cardiomyocyte renewal in humans. Science 324:98-102

175. Olivetti G, Cigola E, Maestri R, Corradi D, Lagrasta C, Gambert SR, Anversa P (1996) Aging, cardiac hypertrophy and ischemic cardiomyopathy do not affect the proportion of mononucleated and multinucleated myocytes in the human heart. J Mol Cell Cardiol 28:1463-1477

176. Mollova M, Bersell K, Walsh S, Savla J, Das LT, Park SY, Silberstein LE, Dos Remedios CG, Graham D, Colan S, Kuhn B (2013) Cardiomyocyte proliferation contributes to heart growth in young humans. Proc Natl Acad Sci USA 110:1446-1451

177. Ahuja P, Sdek P, MacLellan WR (2007) Cardiac myocyte cell cycle control in development, disease, and regeneration. Physiol Rev 87:521-544

178. Mahmoud AI, Kocabas F, Muralidhar SA, Kimura W, Koura AS, Thet S, Porrello ER, Sadek HA (2013) Meis1 regulates postnatal cardiomyocyte cell cycle arrest. Nature 497:249-253

179. Ebelt H, Zhang Y, Kampke A, Xu J, Schlitt A, Buerke M, MullerWerdan U, Werdan K, Braun T (2008) E2F2 expression induces proliferation of terminally differentiated cardiomyocytes in vivo. Cardiovasc Res 80:219-226

180. Lin Z, Zhou P, von Gise A, Gu F, Ma Q, Chen J, Guo H, van Gorp PR, Wang DZ, Pu WT (2015) Pi3kcb links Hippo-YAP and PI3K-AKT signaling pathways to promote cardiomyocyte proliferation and survival. Circ Res 116:35-45

181. Schlesinger J, Schueler M, Grunert M, Fischer JJ, Zhang Q, Krueger T, Lange M, Tonjes M, Dunkel I, Sperling SR (2011) The cardiac transcription network modulated by Gata4, Mef2a, Nkx2.5, Srf, histone modifications, and microRNAs. PLoS Genet 7:e1001313

182. Wang J, Liu S, Heallen T, Martin JF (2018) The Hippo pathway in the heart: pivotal roles in development, disease, and regeneration. Nat Rev Cardiol 15:672-684

183. Ikeda S, Sadoshima J (2016) Regulation of myocardial cell growth and death by the Hippo pathway. Circ J 80:1511-1519

184. Eulalio A, Mano M, Dal Ferro M, Zentilin L, Sinagra G, Zacchigna S, Giacca M (2012) Functional screening identifies miRNAs inducing cardiac regeneration. Nature 492:376-381

185. Torrini C, Cubero RJ, Dirkx E, Braga L, Ali H, Prosdocimo G, Gutierrez MI, Collesi C, Licastro D, Zentilin L, Mano M, Zacchigna S, Vendruscolo M, Marsili M, Samal A, Giacca M (2019) Common regulatory pathways mediate activity of 
microRNAs inducing cardiomyocyte proliferation. Cell Rep 27(9):2759-2771.e5

186. Heallen T, Zhang M, Wang J, Bonilla-Claudio M, Klysik E, Johnson RL, Martin JF (2011) Hippo pathway inhibits Wnt signaling to restrain cardiomyocyte proliferation and heart size. Science 332:458-461

187. Heallen T, Morikawa Y, Leach J, Tao G, Willerson JT, Johnson RL, Martin JF (2013) Hippo signaling impedes adult heart regeneration. Development 140:4683-4690

188. Leach JP, Heallen T, Zhang M, Rahmani M, Morikawa Y, Hill MC, Segura A, Willerson JT, Martin JF (2017) Hippo pathway deficiency reverses systolic heart failure after infarction. Nature 550:260-264

189. Bely AE, Nyberg KG (2010) Evolution of animal regeneration: re-emergence of a field. Trends Ecol Evol 25:161-170

190. Puente BN, Kimura W, Muralidhar SA, Moon J, Amatruda JF, Phelps KL, Grinsfelder D, Rothermel BA, Chen R, Garcia JA, Santos CX, Thet S, Mori E, Kinter MT, Rindler PM, Zacchigna S, Mukherjee S, Chen DJ, Mahmoud AI, Giacca M, Rabinovitch PS, Aroumougame A, Shah AM, Szweda LI, Sadek HA (2014) The oxygen-rich postnatal environment induces cardiomyocyte cell-cycle arrest through DNA damage response. Cell 157:565-579

191. Kadota S, Pabon L, Reinecke H, Murry CE (2017) In vivo maturation of human induced pluripotent stem cell-derived cardiomyocytes in neonatal and adult rat hearts. Stem Cell Rep 8:278-289

192. Cho GS, Lee DI, Tampakakis E, Murphy S, Andersen P, Uosaki $\mathrm{H}$, Chelko S, Chakir K, Hong I, Seo K, Chen HV, Chen X, Basso C, Houser SR, Tomaselli GF, O'Rourke B, Judge DP, Kass DA, Kwon C (2017) Neonatal transplantation confers maturation of PSC-derived cardiomyocytes conducive to modeling cardiomyopathy. Cell Rep 18:571-582

193. Ribeiro MC, Tertoolen LG, Guadix JA, Bellin M, Kosmidis G, D’Aniello C, Monshouwer-Kloots J, Goumans MJ, Wang YL, Feinberg AW, Mummery CL, Passier R (2015) Functional maturation of human pluripotent stem cell derived cardiomyocytes in vitro-correlation between contraction force and electrophysiology. Biomaterials 51:138-150

194. Li RK, Mickle DA, Weisel RD, Carson S, Omar SA, Tumiati LC, Wilson GJ, Williams WG (1996) Human pediatric and adult ventricular cardiomyocytes in culture: assessment of phenotypic changes with passaging. Cardiovasc Res 32:362-373

195. Polak S, Fijorek K (2012) Inter-individual variability in the preclinical drug cardiotoxic safety assessment-analysis of the agecardiomyocytes electric capacitance dependence. J Cardiovasc Transl Res 5:321-332

196. Scuderi GJ, Butcher J (2017) Naturally engineered maturation of cardiomyocytes. Front Cell Dev Biol 5:50

197. Gerdes AM, Kellerman SE, Moore JA, Muffly KE, Clark LC, Reaves PY, Malec KB, McKeown PP, Schocken DD (1992) Structural remodeling of cardiac myocytes in patients with ischemic cardiomyopathy. Circulation 86:426-430

198. Tulloch NL, Muskheli V, Razumova MV, Korte FS, Regnier M, Hauch KD, Pabon L, Reinecke H, Murry CE (2011) Growth of engineered human myocardium with mechanical loading and vascular coculture. Circ Res 109:47-59

199. Zimmermann WH, Schneiderbanger K, Schubert P, Didie M, Munzel F, Heubach JF, Kostin S, Neuhuber WL, Eschenhagen $\mathrm{T}$ (2002) Tissue engineering of a differentiated cardiac muscle construct. Circ Res 90:223-230

200. Ronaldson-Bouchard K, Ma SP, Yeager K, Chen T, Song L, Sirabella D, Morikawa K, Teles D, Yazawa M, Vunjak-Novakovic G (2018) Advanced maturation of human cardiac tissue grown from pluripotent stem cells. Nature 556:239-243

201. Schaaf S, Shibamiya A, Mewe M, Eder A, Stohr A, Hirt MN, Rau T, Zimmermann WH, Conradi L, Eschenhagen T, Hansen A
(2011) Human engineered heart tissue as a versatile tool in basic research and preclinical toxicology. PLoS ONE 6:e26397

202. van den Heuvel NH, van Veen TA, Lim B, Jonsson MK (2014) Lessons from the heart: mirroring electrophysiological characteristics during cardiac development to in vitro differentiation of stem cell derived cardiomyocytes. J Mol Cell Cardiol 67:12-25

203. Ma J, Guo L, Fiene SJ, Anson BD, Thomson JA, Kamp TJ, Kolaja KL, Swanson BJ, January CT (2011) High purity humaninduced pluripotent stem cell-derived cardiomyocytes: electrophysiological properties of action potentials and ionic currents. Am J Physiol Heart Circ Physiol 301:H2006-2017

204. Keung W, Boheler KR, Li RA (2014) Developmental cues for the maturation of metabolic, electrophysiological and calcium handling properties of human pluripotent stem cell-derived cardiomyocytes. Stem Cell Res Ther 5:17

205. Bhute VJ, Bao X, Dunn KK, Knutson KR, McCurry EC, Jin G, Lee WH, Lewis S, Ikeda A, Palecek SP (2017) Metabolomics identifies metabolic markers of maturation in human pluripotent stem cell-derived cardiomyocytes. Theranostics 7:2078-2091

206. Nose N, Werner RA, Ueda Y, Gunther K, Lapa C, Javadi MS, Fukushima K, Edenhofer F, Higuchi T (2018) Metabolic substrate shift in human induced pluripotent stem cells during cardiac differentiation: functional assessment using in vitro radionuclide uptake assay. Int J Cardiol 269:229-234

207. Nakano H, Minami I, Braas D, Pappoe H, Wu X, Sagadevan A, Vergnes L, Fu K, Morselli M, Dunham C, Ding X, Stieg AZ, Gimzewski JK, Pellegrini M, Clark PM, Reue K, Lusis AJ, Ribalet B, Kurdistani SK, Christofk H, Nakatsuji N, Nakano A (2017) Glucose inhibits cardiac muscle maturation through nucleotide biosynthesis. Elife 6:e29330

208. McDevitt TC, Laflamme MA, Murry CE (2005) Proliferation of cardiomyocytes derived from human embryonic stem cells is mediated via the IGF/PI 3-kinase/Akt signaling pathway. $\mathrm{J}$ Mol Cell Cardiol 39:865-873

209. Lundy SD, Zhu WZ, Regnier M, Laflamme MA (2013) Structural and functional maturation of cardiomyocytes derived from human pluripotent stem cells. Stem Cells Dev 22:1991-2002

210. Piccini I, Rao J, Seebohm G, Greber B (2015) Human pluripotent stem cell-derived cardiomyocytes: Genome-wide expression profiling of long-term in vitro maturation in comparison to human heart tissue. Genom Data 4:69-72

211. Veerman CC, Kosmidis G, Mummery CL, Casini S, Verkerk AO, Bellin M (2015) Immaturity of human stem-cell-derived cardiomyocytes in culture: fatal flaw or soluble problem? Stem Cells Dev 24:1035-1052

212. Dias TP, Pinto SN, Santos JI, Fernandes TG, Fernandes F, Diogo MM, Prieto M, Cabral JMS (2018) Biophysical study of human induced pluripotent stem cell-derived cardiomyocyte structural maturation during long-term culture. Biochem Biophys Res Commun 499:611-617

213. Kamakura T, Makiyama T, Sasaki K, Yoshida Y, Wuriyanghai Y, Chen J, Hattori T, Ohno S, Kita T, Horie M, Yamanaka S, Kimura T (2013) Ultrastructural maturation of human-induced pluripotent stem cell-derived cardiomyocytes in a long-term culture. Circ J 77:1307-1314

214. Leonard A, Bertero A, Powers JD, Beussman KM, Bhandari S, Regnier M, Murry CE, Sniadecki NJ (2018) Afterload promotes maturation of human induced pluripotent stem cell derived cardiomyocytes in engineered heart tissues. J Mol Cell Cardiol 118:147-158

215. Tiburcy M, Hudson JE, Balfanz P, Schlick S, Meyer T, Chang Liao ML, Levent E, Raad F, Zeidler S, Wingender E, Riegler J, Wang M, Gold JD, Kehat I, Wettwer E, Ravens U, Dierickx P, van Laake LW, Goumans MJ, Khadjeh S, Toischer K, Hasenfuss G, Couture LA, Unger A, Linke WA, Araki T, Neel B, Keller G, Gepstein L, Wu JC, Zimmermann WH (2017) 
Defined engineered human myocardium with advanced maturation for applications in heart failure modeling and repair. Circulation 135:1832-1847

216. Ribeiro AJ, Ang YS, Fu JD, Rivas RN, Mohamed TM, Higgs GC, Srivastava D, Pruitt BL (2015) Contractility of single cardiomyocytes differentiated from pluripotent stem cells depends on physiological shape and substrate stiffness. Proc Natl Acad Sci USA 112:12705-12710

217. Nunes SS, Miklas JW, Liu J, Aschar-Sobbi R, Xiao Y, Zhang B, Jiang J, Masse S, Gagliardi M, Hsieh A, Thavandiran N, Laflamme MA, Nanthakumar K, Gross GJ, Backx PH, Keller G, Radisic M (2013) Biowire: a platform for maturation of human pluripotent stem cell-derived cardiomyocytes. Nat Methods 10:781-787

218. Ruan JL, Tulloch NL, Razumova MV, Saiget M, Muskheli V, Pabon L, Reinecke H, Regnier M, Murry CE (2016) Mechanical stress conditioning and electrical stimulation promote contractility and force maturation of induced pluripotent stem cell-derived human cardiac tissue. Circulation 134:1557-1567

219. Kensah G, Roa Lara A, Dahlmann J, Zweigerdt R, Schwanke K, Hegermann J, Skvorc D, Gawol A, Azizian A, Wagner S, Maier LS, Krause A, Drager G, Ochs M, Haverich A, Gruh I, Martin U (2013) Murine and human pluripotent stem cell-derived cardiac bodies form contractile myocardial tissue in vitro. Eur Heart J 34:1134-1146

220. Shadrin IY, Allen BW, Qian Y, Jackman CP, Carlson AL, Juhas ME, Bursac N (2017) Cardiopatch platform enables maturation and scale-up of human pluripotent stem cell-derived engineered heart tissues. Nat Commun 8:1825

221. Lee DS, Chen JH, Lundy DJ, Liu CH, Hwang SM, Pabon L, Shieh RC, Chen CC, Wu SN, Yan YT, Lee ST, Chiang PM, Chien S, Murry CE, Hsieh PC (2015) Defined microRNAs induce aspects of maturation in mouse and human embryonicstem-cell-derived cardiomyocytes. Cell Rep 12:1960-1967

222. Carson D, Hnilova M, Yang X, Nemeth CL, Tsui JH, Smith AS, Jiao A, Regnier M, Murry CE, Tamerler C, Kim DH (2016) Nanotopography-induced structural anisotropy and sarcomere development in human cardiomyocytes derived from induced pluripotent stem cells. ACS Appl Mater Interfaces 8:21923-21932

223. Pioner JM, Racca AW, Klaiman JM, Yang KC, Guan X, Pabon L, Muskheli V, Zaunbrecher R, Macadangdang J, Jeong MY, Mack DL, Childers MK, Kim DH, Tesi C, Poggesi C, Murry CE, Regnier M (2016) Isolation and mechanical measurements of myofibrils from human induced pluripotent stem cell-derived cardiomyocytes. Stem Cell Rep 6:885-896
224. Smith AST, Yoo H, Yi H, Ahn EH, Lee JH, Shao G, Nagornyak E, Laflamme MA, Murry CE, Kim DH (2017) Micro- and nanopatterned conductive graphene-PEG hybrid scaffolds for cardiac tissue engineering. Chem Commun (Camb) 53:7412-7415

225. Rupert CE, Coulombe KLK (2017) IGF1 and NRG1 enhance proliferation, metabolic maturity, and the force-frequency response in hESC-derived engineered cardiac tissues. Stem Cells Int 2017:7648409

226. Lee YK, Ng KM, Chan YC, Lai WH, Au KW, Ho CY, Wong LY, Lau CP, Tse HF, Siu CW (2010) Triiodothyronine promotes cardiac differentiation and maturation of embryonic stem cells via the classical genomic pathway. Mol Endocrinol 24:1728-1736

227. Kuppusamy KT, Jones DC, Sperber H, Madan A, Fischer KA, Rodriguez ML, Pabon L, Zhu WZ, Tulloch NL, Yang X, Sniadecki NJ, Laflamme MA, Ruzzo WL, Murry CE, Ruohola-Baker $\mathrm{H}$ (2015) Let-7 family of microRNA is required for maturation and adult-like metabolism in stem cell-derived cardiomyocytes. Proc Natl Acad Sci USA 112:E2785-2794

228. Reinecke H, Zhang M, Bartosek T, Murry CE (1999) Survival, integration, and differentiation of cardiomyocyte grafts: a study in normal and injured rat hearts. Circulation 100:193-202

229. Hockemeyer D, Jaenisch R (2016) Induced pluripotent stem cells meet genome editing. Cell Stem Cell 18:573-586

230. Wright AV, Nunez JK, Doudna JA (2016) Biology and applications of crispr systems: harnessing nature's toolbox for genome engineering. Cell 164:29-44

231. Zhu WZ, Santana LF, Laflamme MA (2009) Local control of excitation-contraction coupling in human embryonic stem cellderived cardiomyocytes. PLoS ONE 4:e5407

232. Tsukamoto S, Fujii T, Oyama K, Shintani SA, Shimozawa T, Kobirumaki-Shimozawa F, Ishiwata S, Fukuda N (2016) Simultaneous imaging of local calcium and single sarcomere length in rat neonatal cardiomyocytes using yellow Cameleon-Nano140. J Gen Physiol 148:341-355

233. Schram G, Pourrier M, Wang Z, White M, Nattel S (2003) Barium block of Kir2 and human cardiac inward rectifier currents: evidence for subunit-heteromeric contribution to native currents. Cardiovasc Res 59:328-338

Publisher's Note Springer Nature remains neutral with regard to jurisdictional claims in published maps and institutional affiliations. 